\title{
Reconstructing the thermal structure of the upper ocean: Insights from planktic foraminifera shell chemistry and alkenones in modern sediments of the tropical eastern Indian Ocean
}

\author{
Mahyar Mohtadi, ${ }^{1}$ Delia W. Oppo, ${ }^{2}$ Andreas Lückge, ${ }^{3}$ Ricardo DePol-Holz, ${ }^{4,5}$ \\ Stephan Steinke, ${ }^{1}$ Jeroen Groeneveld, ${ }^{1,6}$ Nils Hemme, ${ }^{7}$ and Dierk Hebbeln ${ }^{1}$ \\ Received 15 February 2011; revised 7 June 2011; accepted 13 June 2011; published 10 September 2011.
}

[1] Shell chemistry of planktic foraminifera and the alkenone unsaturation index in 69 surface sediment samples in the tropical eastern Indian Ocean off West and South Indonesia were studied. Results were compared to modern hydrographic data in order to assess how modern environmental conditions are preserved in sedimentary record, and to determine the best possible proxies to reconstruct seasonality, thermal gradient and upper water column characteristics in this part of the world ocean. Our results imply that alkenone-derived temperatures record annual mean temperatures in the study area. However, this finding might be an artifact due to the temperature limitation of this proxy above $28^{\circ} \mathrm{C}$. Combined study of shell stable oxygen isotope and $\mathrm{Mg} / \mathrm{Ca}$ ratio of planktic foraminifera suggests that Globigerinoides ruber sensu stricto (s.s.), G. ruber sensu lato (s.l.), and G. sacculifer calcify within the mixed-layer between $20 \mathrm{~m}$ and $50 \mathrm{~m}$, whereas Globigerina bulloides records mixed-layer conditions at $\sim 50 \mathrm{~m}$ depth during boreal summer. Mean calcifications of Pulleniatina obliquiloculata, Neogloboquadrina dutertrei, and Globorotalia tumida occur at the top of the thermocline during boreal summer, at $\sim 75 \mathrm{~m}$, 75-100 m, and $100 \mathrm{~m}$, respectively. Shell $\mathrm{Mg} / \mathrm{Ca}$ ratios of all species show a significant correlation with temperature at their apparent calcification depths and validate the application of previously published temperature calibrations, except for G. tumida that requires a regional $\mathrm{Mg} / \mathrm{Ca}$-temperature calibration $(\mathrm{Mg} / \mathrm{Ca}=0.41 \exp (0.068 * \mathrm{~T}))$. We show that the difference in $\mathrm{Mg} / \mathrm{Ca}$-temperatures of the mixed-layer species and the thermocline species, particularly between $G$. ruber s.s. (or s.1.) and P. obliquiloculata, can be applied to track changes in the upper water column stratification. Our results provide critical tools for reconstructing past changes in the hydrography of the study area and their relation to monsoon, El Niño-Southern Oscillation, and the Indian Ocean Dipole Mode.

Citation: Mohtadi, M., D. W. Oppo, A. Lückge, R. DePol-Holz, S. Steinke, J. Groeneveld, N. Hemme, and D. Hebbeln (2011), Reconstructing the thermal structure of the upper ocean: Insights from planktic foraminifera shell chemistry and alkenones in modern sediments of the tropical eastern Indian Ocean, Paleoceanography, 26, PA3219, doi:10.1029/2011PA002132.

\section{Introduction}

[2] In the tropical Indo-Pacific, semi- and inter-annual changes in the wind strength and precipitation mainly caused

\footnotetext{
${ }^{1}$ MARUM-Center for Marine Environmental Sciences, University of Bremen, Bremen, Germany.

${ }^{2}$ Department of Geology and Geophysics, Woods Hole Oceanographic Institution, Woods Hole, Massachusetts, USA.

${ }^{3}$ Federal Institute for Geosciences and Natural Resources, Hannover, Germany.

${ }^{4}$ Earth System Science Department, University of California, Irvine, California, USA.

${ }^{5}$ Now at Department of Oceanography, University of Concepción, Concepción, Chile.

${ }^{6}$ Alfred Wegener Institute for Polar and Marine Research, Bremerhaven, Germany.

${ }^{7}$ Faculty of Geosciences, University of Bremen, Bremen, Germany.

Copyright 2011 by the American Geophysical Union. 0883-8305/11/2011PA002132
}

by monsoon, El Niño-Southern Oscillation (ENSO), and the Indian Ocean Dipole Mode (IOD), significantly affect the thickness and evolution of the mixed-layer and the thermocline as well as the intensity and direction of the surface and subsurface circulation [e.g., Susanto et al., 2001; Rao et al., 2002; Gordon, 2005; Qu and Meyers, 2005]. Reconstruction of the upper water column structure in this region therefore can provide critical information for understanding past behavior of these climate systems and the mechanisms of past, and future, regional climate change.

[3] The vertical structure of the water column can be best reconstructed by using differences in a geochemical proxy for temperature such as shell stable oxygen isotopes $\left(\delta^{18} \mathrm{O}\right)$ or $\mathrm{Mg} / \mathrm{Ca}$ ratios of various planktic foraminifera species that thrive at different water depths due to their preferred range of temperature, salinity, chlorophyll, light, etc. [e.g., Fairbanks et al., 1980; 1982; Hemleben et al., 1989; Sautter and Thunell, 1991; Ortiz et al., 1995]. As habitat depths of planktic fora- 
minifera vary in different regions due to different hydrographic characteristics, it is crucial to determine the regional habitat and calcification depths of various species, their seasonality and their environmental control [e.g., Elderfield and Ganssen, 2000; Anand et al., 2003; Mulitza et al., 2003; McConnell and Thunell, 2005; Farmer et al., 2007; Cléroux et al., 2008; Mohtadi et al., 2009; Regenberg et al., 2009; Steph et al., 2009] in order to minimize errors in paleoceanographic reconstructions based on $\delta^{18} \mathrm{O}$ or $\mathrm{Mg} / \mathrm{Ca}$.

[4] Here we present paired $\mathrm{Mg} / \mathrm{Ca}$ and $\delta^{18} \mathrm{O}$ measurements on seven planktic foraminifera species in 69 sediment surface samples from the eastern equatorial Indian Ocean, $\mathrm{W}$ and $\mathrm{S}$ off Indonesia. We use shell $\delta^{18} \mathrm{O}$ to infer calcification depths for different species, and compare the shell $\mathrm{Mg} / \mathrm{Ca}$ ratio with the modern temperature data that correspond to the inferred calcification depths. In addition, we evaluate published $\mathrm{Mg} / \mathrm{Ca}$-temperature calibrations in order to assess the best possible modern calibration of this temperature proxy for the eastern equatorial Indian Ocean. We further analyze alkenone-derived sea surface temperatures (SST) in the same surface samples to compare different SST proxies and to assess how modern environmental conditions are preserved in surface sediments. Finally, we introduce different proxies to reconstruct thermal gradients and upper water column characteristics that help to assess past behavior of ENSO, monsoon, and IOD from sedimentary records in the tropical eastern Indian Ocean.

\section{Study Area}

[5] The study area is part of the Indo-Pacific Warm Pool with mean SST generally exceeding $28^{\circ} \mathrm{C}$. The seasonal climate in this region is affected by the Australian-Indonesian monsoon (AIM) winds [e.g., Tapper, 2002; Qu and Meyers, 2005; Kida and Richards, 2009]. The northern and southern portions of the study area are characterized by different seasonality. During the SE monsoon from June-September (boreal summer), alongshore winds induce Ekman pumping and coastal upwelling off S and SW Indonesia that decrease SST by $1-2^{\circ} \mathrm{C}$ (Figure $\mathrm{S} 1$ in the auxiliary material) and increase chlorophyll $a$ concentrations south of $4^{\circ} \mathrm{S}$ (Figure 1a). ${ }^{1}$ The NW monsoon season from December to March is characterized by the southward progression of the Intertropical Convergence Zone (ITCZ), increased precipitation, a rather uniform SST distribution, and low chlorophyll $a$ concentrations in the entire tropical eastern Indian Ocean (Figure 1b). In contrast to off S and SW Indonesia, a relatively thick mixedlayer of about 70-80 m persists throughout the year off $\mathrm{W}$ and NW Indonesia (Figures 1a, 1b, and S1). Surface salinity varies between 33.5 and 34.2 psu in the study area (Figure S2). Seasonal salinity changes are rather small in both regions, with maximum variability of about 0.6 psu in the upwelling areas off southern Indonesia (Figure S2).

[6] On inter-annual timescales, ENSO and the IOD strongly affect the hydrography of the equatorial Indian Ocean [e.g., Susanto et al., 2001; Qu and Meyers, 2005; Susanto and Marra, 2005; Zhong et al., 2005; Halkides et al., 2006; Du et al., 2008; Horii et al., 2008]. Briefly, El Niño and positive IOD years are associated with anomalously strong

\footnotetext{
${ }^{1}$ Auxiliary materials are available in the HTML. doi:10.1029/ 2011PA002132.
}

SE winds that reinforce coastal upwelling and induce up to $5^{\circ} \mathrm{C}$ decrease in SST and higher primary production off S and SW Indonesia during boreal summer (Figures 1c-1e). In contrast, La Niña and negative IOD years amplify the NW monsoon climatic features, i.e., enhanced westerly winds, positive precipitation anomalies, and a uniformly high SST in the study area (Figure 1f).

\section{Material and Methods}

\subsection{Sampling}

[7] Surface sediment samples were collected during the RV SONNE cruises 184 (34 samples) [Hebbeln et al., 2005] and 189 (35 samples) [Wiedicke-Hombach et al., 2007] from off $\mathrm{W}$ and $\mathrm{S}$ Indonesia (Figure 2 and Table 1). The top $1 \mathrm{~cm}$ of multicore samples were freeze-dried, washed and sieved for the planktic foraminifera study, and freeze-dried and ground for alkenone analyses, respectively. In order to address different environmental conditions in the study area both on the seasonal and interannual timescales, we grouped the sample material in seven different basins (Figure 2). The Simeulue Basin (SB) off NW Sumatra, the Nias Basin (NB) south of the SB, and the Northern Mentawai Basin (NMB) off W Sumatra are characterized by oligotrophic to mesotrophic conditions and insignificant seasonal and interannual variations in marine productivity, SST, and thermocline depth. In contrast, the Southern Mentawai Basin (SMB), the Java Basin (JB), the Lombok Basin (LB), and the Savu Sea (SS) show a pronounced seasonality of the upper water column structure, primary productivity, and SST due to the occurrence of coastal upwelling in boreal summer.

[8] A study by Mohtadi et al. [2007] on the same surface samples showed that carbonate dissolution can be neglected in this set of samples, as either the basins lack the aragonite lysocline (SB, NB, NMB and SMB), or the samples are retrieved from water depths well above the calcite lysocline (JB, LB, SS) and do not show any evidence of selective calcite dissolution.

\subsection{Radiocarbon Analyses}

[9] Radiocarbon dating was performed on 16 selected surface sediments from all of the different basins in the study area (Table 2). Samples were measured at the Keck Carbon Cycle Accelerator Mass Spectrometry Laboratory, University of California, Irvine (UCI), and at the National Ocean Sciences Accelerator Mass Spectrometry Facility, Woods Hole (OS). UCI samples contained mono-species tests of Globigerinoides sacculifer (without sac-like final chamber), while OS samples included multispecies tests of planktic foraminifera. Radiocarbon ages were converted to calendar ages using Marine 09 calibration [Hughen et al., 2004] of CALIB 6.0 software assuming no deviation from the global ocean carbon reservoir.

\subsection{Planktic Foraminifera}

[10] For all analyses presented in this study, we used whole tests of Globigerinoides ruber sensu stricto (s.s.), G. ruber sensu lato (s.l.), and Globigerina bulloides from the 250-355 $\mu \mathrm{m}$ size fraction, and of G. sacculifer (without saclike final chamber), Neogloboquadrina dutertrei, Pulleniatina obliquiloculata, and Globorotalia tumida from the $355-500 \mu \mathrm{m}$ size fraction, respectively. Determination of 

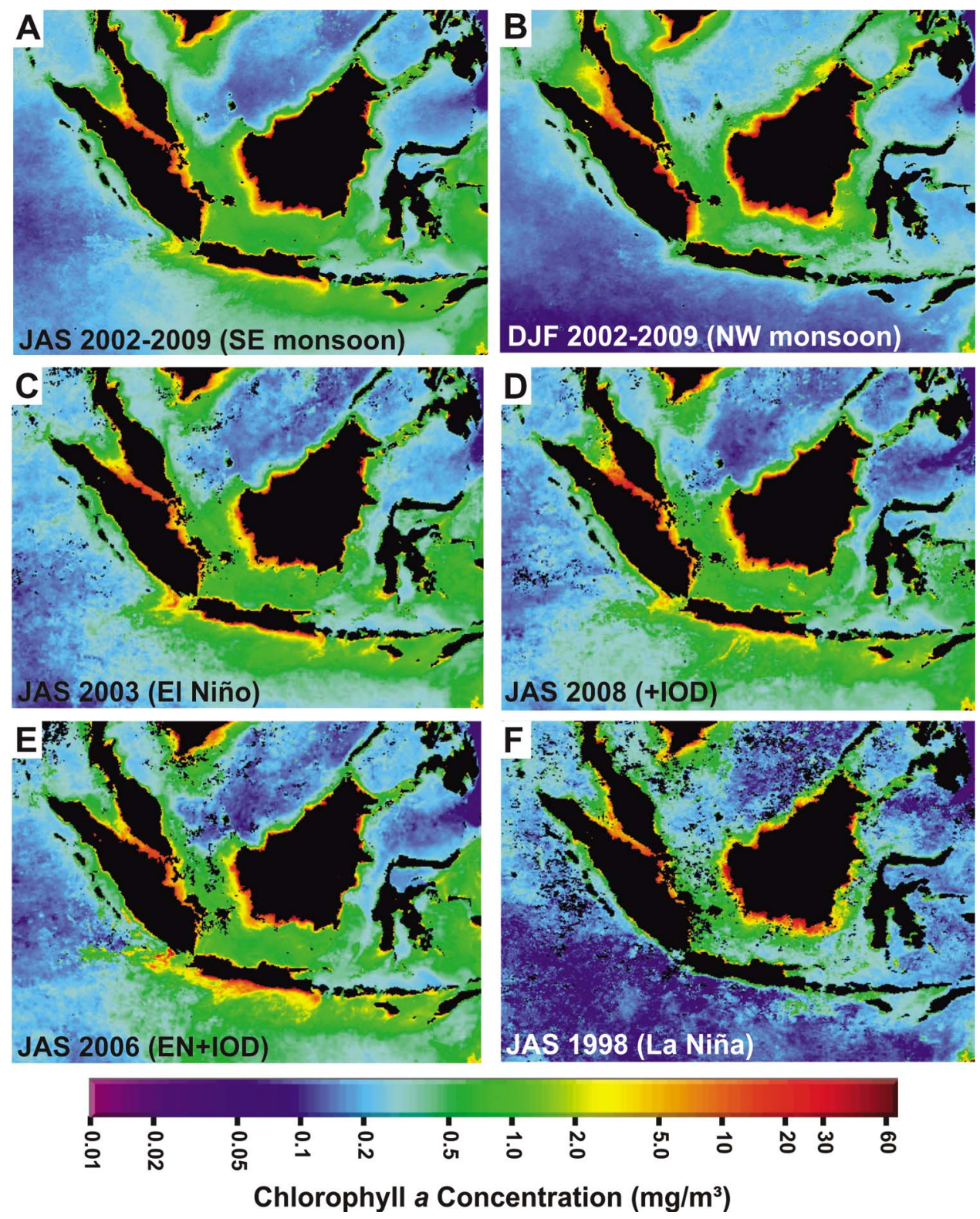

Figure 1. Remote sensing images of the mean seasonal chlorophyll $a$ concentration around Indonesia (http://oceancolor.gsfc.nasa.gov). Mean values between 2002 and 2009 during (a) the SE monsoon (July-September) and the (b) NW monsoon (December-February) seasons. Here, the effect of monsoon-related seasonal upwelling off S and SW Indonesia is apparent. Chlorophyll $a$ concentrations (July-September) during (c) a moderate El Niño year (2003) and (d) a positive IOD year (2008). Chlorophyll $a$ concentrations (July-September) during (e) a positive IOD/El Niño year (2006), and (f) a strong La Niña year (1998). Note the enhanced (reduced) chlorophyll $a$ concentrations off S and SW Indonesia during the positive IOD/El Niño (La Niña) years indicative of intensified (weakened) upwelling.

G. ruber s.s. and s.l. follows the concept of Wang [2000], in which $G$. ruber s.l. corresponds to the more compact and higher trochospiral forms previously described as G. elongatus [d'Orbigny, 1826], G. pyramidalis [Van den Broeck, 1876], and G. cyclostomus [Galloway and Wissler, 1927].

\subsubsection{Oxygen Isotope and $\mathrm{Mg} / \mathrm{Ca}$ Analyses}

[11] A Finnigan MAT 251 mass spectrometer was used to measure the $\delta^{18} \mathrm{O}$ composition of the planktic foraminifera (Table 1). Approximately 5-20 individual tests were picked for each measurement. The isotopic composition of the carbonate sample was measured on the $\mathrm{CO}_{2}$ gas evolved by treatment with phosphoric acid at a constant temperature of $75^{\circ} \mathrm{C}$. For all stable isotope measurements a standard gas (Burgbrohl $\mathrm{CO}_{2}$ gas) was used. Samples were calibrated against PDB by using the NBS 19 and an internal laboratory standard (Solnhofen Limestone). All isotopic data given here are relative to the PDB standard. Analytical standard deviation is about $\pm 0.07 \%$ (Isotope Laboratory, Faculty of Geosciences, University of Bremen).

[12] For $\mathrm{Mg} / \mathrm{Ca}$ analyses, planktic foraminifera tests were utilized from the same size fraction as for the $\delta^{18} \mathrm{O}$ analyses. Samples contained about 30-40 intact tests of G. ruber s.s., 


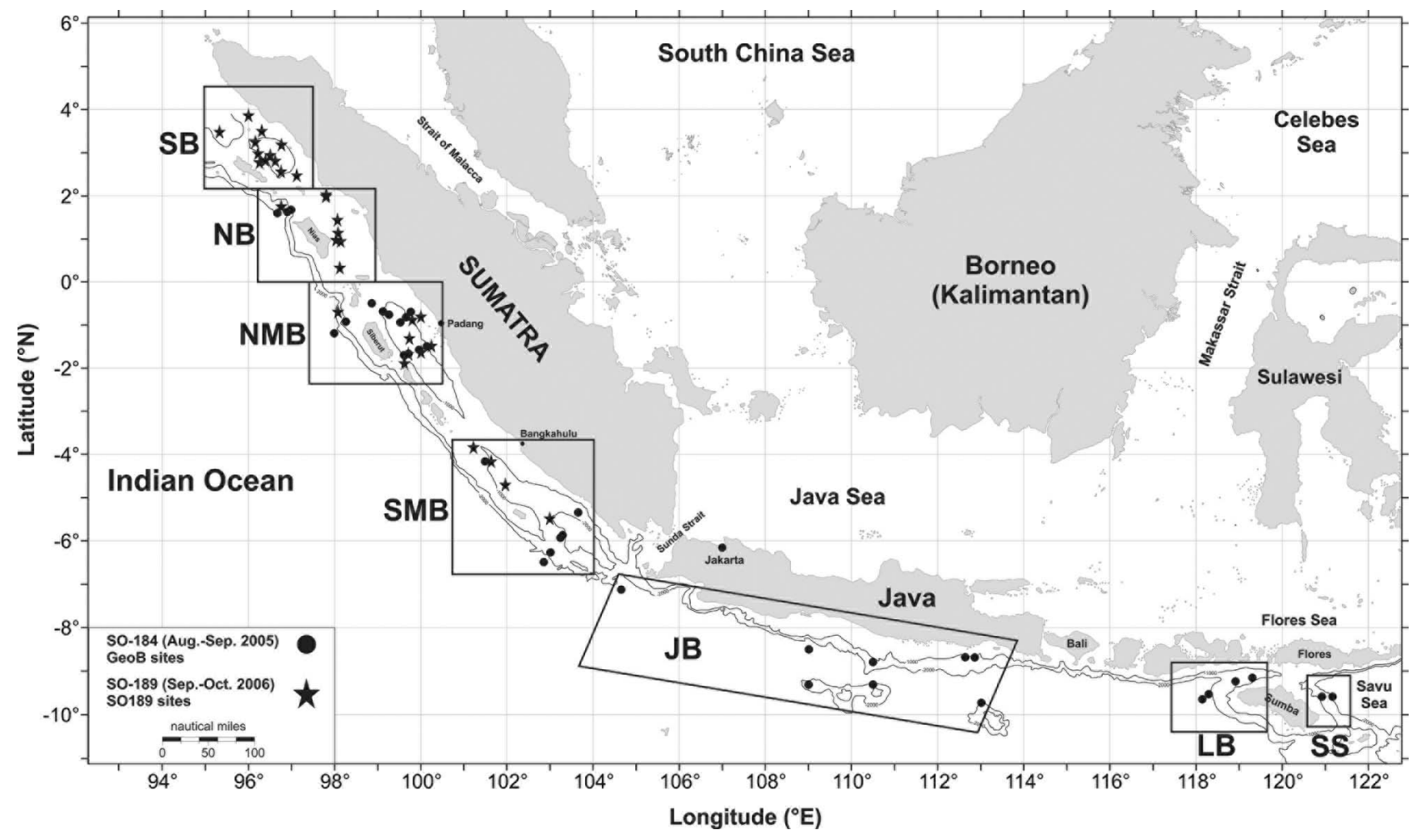

Figure 2. Schematic map of the study area showing the position of the investigated surface sediments collected during the SO-184 (dots) and SO-189 (stars) cruises. Rectangles indicate different fore-arc basins. SB: Simeulue Basin; NB: Nias Basin; NMB: Northern Mentawai Basin; SMB: Southern Mentawai Basin; JB: Java Basin; LB: Lombok Basin; SS: Savu Sea. The four southern basins are characterized by seasonal upwelling during boreal summer.

G. ruber s.l., G. sacculifer, $P$. obliquiloculata, and $N$. dutertrei, about 40-50 tests of $G$. bulloides, and about 10-15 tests of $G$. tumida. Samples were cleaned applying a modified method originally proposed by Barker et al. [2003] consisting of five water washes and two methanol washes followed by two oxidation steps with $1 \% \mathrm{NaOH}$-buffered $\mathrm{H}_{2} \mathrm{O}_{2}$, and a weak acid leach with $0.001 \mathrm{M}$ QD $\mathrm{HNO}_{3}$. Samples were then dissolved into 0.075M QD $\mathrm{HNO}_{3}$ and centrifuged for $10 \mathrm{~min}$. at $6000 \mathrm{rpm}$, transferred into test tubes and diluted. $\mathrm{Mg} / \mathrm{Ca}$ ratios were measured using a Perkin Elmer Optima 3300 R Inductively Coupled Plasma Optical Emission Spectrophotometer (ICP-OES) equipped with an auto sampler and an ultrasonic nebulizer U-5000 AT (Cetac Technologies Inc.) housed at the Faculty of Geosciences, University of Bremen. The $\mathrm{Mg} / \mathrm{Ca}$ values are reported as mmol $\mathrm{mol}^{-1}$. Instrumental precision was determined using an external, in-house standard $(\mathrm{Mg} / \mathrm{Ca}=$ $2.92 \mathrm{mmol} \mathrm{mol}^{-1}$ ), which was run after every fifth sample. Relative standard deviation was $0.01 \mathrm{mmol} \mathrm{mol}^{-1}(0.34 \%)$ for the external standard and $\sim 0.48 \%$ for the ECRM $752-$ 1 standard [Greaves et al., 2008]. Replicate measurements on 36 samples revealed an average standard deviation of $0.11 \mathrm{mmol} \mathrm{mol}^{-1}$. $\mathrm{Fe} / \mathrm{Ca}, \mathrm{Mn} / \mathrm{Ca}$, and $\mathrm{Al} / \mathrm{Ca}$ ratios were determined in conjunction with $\mathrm{Mg} / \mathrm{Ca}$ as clay contamination and post-depositional $\mathrm{Mn}$-rich carbonate coatings can exert a significant control on $\mathrm{Mg} / \mathrm{Ca}$ ratios [Rosenthal et al., 2000]. We exclude this possibility as these ratios were small in all samples $\left(<0.1 \mathrm{mmol} \mathrm{mol}^{-1}\right.$ for $\mathrm{Mn} / \mathrm{Ca}$ and $\mathrm{Fe} / \mathrm{Ca}$, and not detectable, i.e., $<0 \mathrm{mmol} \mathrm{mol}^{-1}$, for $\left.\mathrm{Al} / \mathrm{Ca}\right)$.

\subsubsection{Calcification Depths}

[13] To estimate the calcification depths for all species, the measured $\delta^{18} \mathrm{O}$ values of planktic foraminifera were compared to the expected equilibrium $\delta^{18} \mathrm{O}$ of calcite at different water depths. Seawater $\delta^{18} \mathrm{O}\left(\delta^{18} \mathrm{O}_{\mathrm{Sw}}\right)$ was calculated for six different water depths at $0 \mathrm{~m}, 20 \mathrm{~m}, 50 \mathrm{~m}, 75 \mathrm{~m}, 100 \mathrm{~m}$, and $150 \mathrm{~m}$ from the WOA 05 salinity data [Antonov et al., 2006] using the salinity- $\delta^{18} \mathrm{O}_{\mathrm{SW}}$ relationship of Morimoto et al. [2002] for the Western Pacific Warm Pool:

$$
\delta^{18} \mathrm{O}_{\mathrm{SW}}(\mathrm{SMOW})=-14.3+0.42 \text { salinity }
$$

[14] The Standard Mean Ocean Water (SMOW) values were converted to the PDB scale by subtracting $0.27 \%$. In a next step, species-specific $\delta^{18} \mathrm{O}$-temperature equations were used to calculate the equilibrium $\delta^{18} \mathrm{O}$ of calcite (Table 3). Bemis et al. [1998] demonstrated that linear and quadratic equations provide equally good fits at warm ocean temperatures. Therefore, we only used $\delta^{18} \mathrm{O}$-temperature equations with a linear relationship (Table 3 ). The water depth in which the expected equilibrium $\delta^{18} \mathrm{O}$ of calcite matches the measured $\delta^{18} \mathrm{O}$ values of planktic foraminifera is assumed to approximate the mean calcification depth of each species.

[15] Several studies have shown that physiological (vital) effects influence the shell isotopic composition of planktic foraminifera and result in shell $\delta^{18} \mathrm{O}$ disequilibrium with the ambient water, ranging between $-1 \%$ and $0.5 \%$ [see e.g., Niebler et al., 1999, and references therein]. Correcting the 


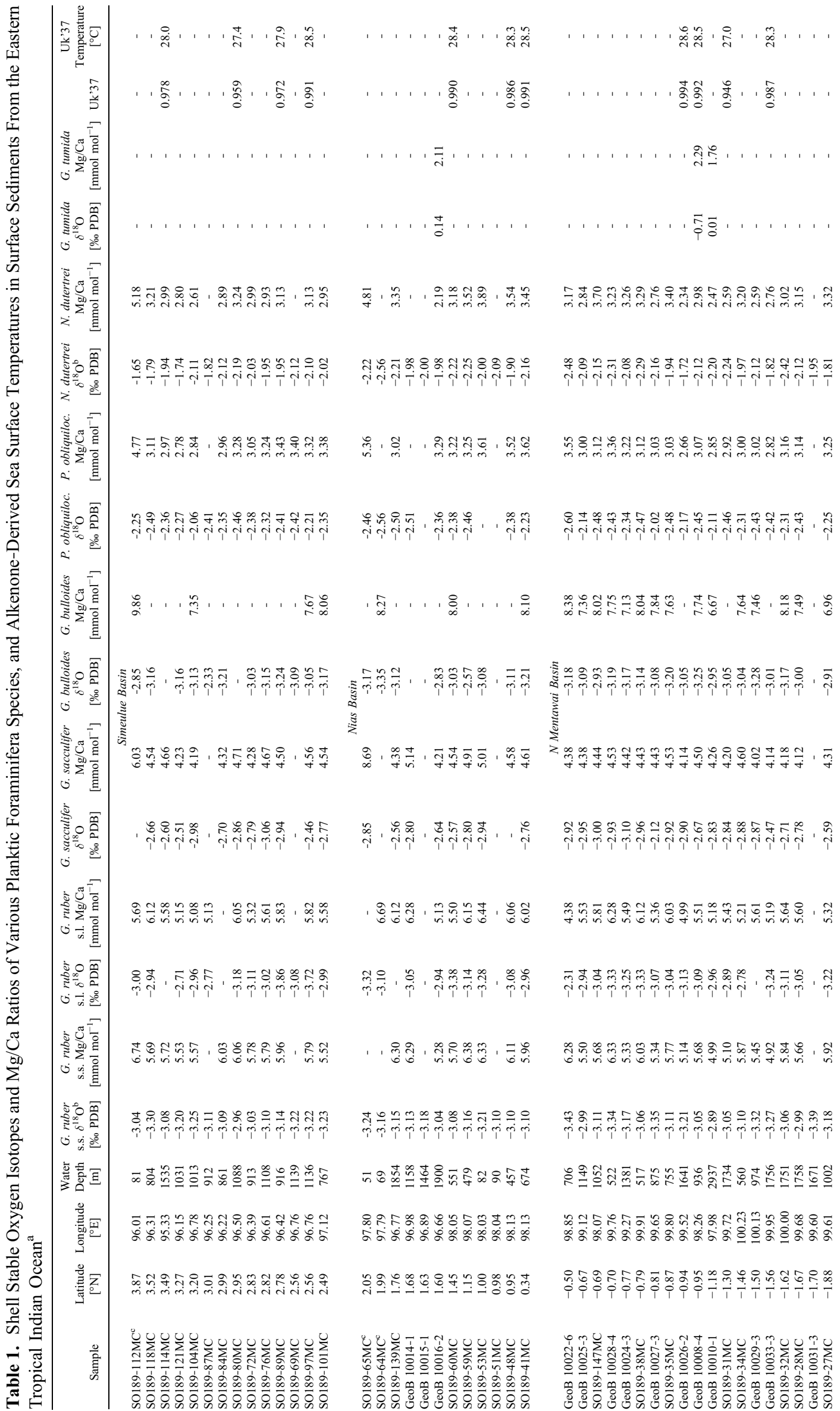




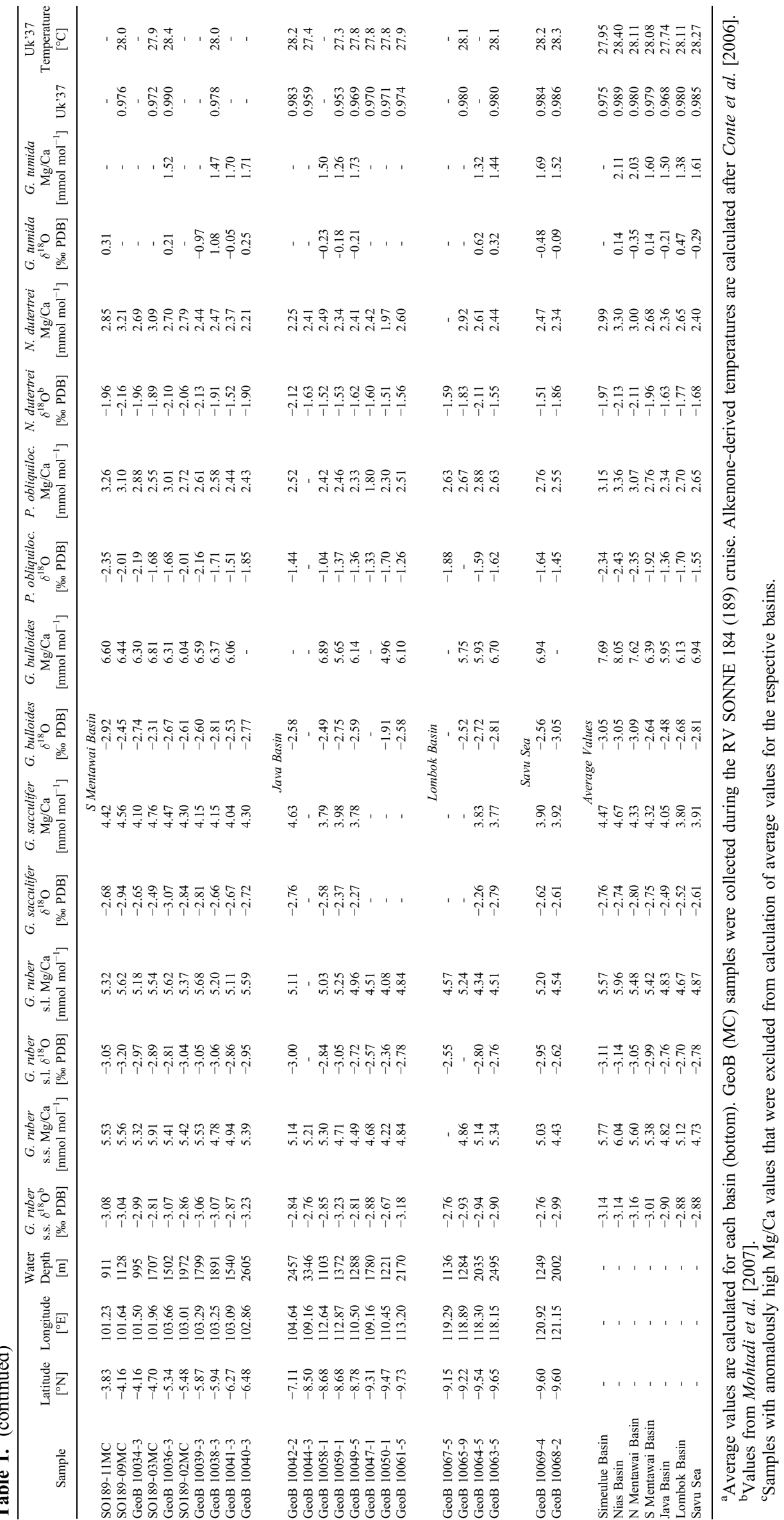


Table 2. Radiocarbon Dating on Selected Surface Sediments From the Eastern Tropical Indian Ocean ${ }^{\mathrm{a}}$

\begin{tabular}{|c|c|c|c|c|c|}
\hline Surface Sample $[0-1 \mathrm{~cm}]$ & Lab-ID & Species & $\begin{array}{c}{ }^{14} \mathrm{C} \text { Age } \\
\text { [years] }\end{array}$ & $\begin{array}{l} \pm \text { Error } \\
\text { [years] }\end{array}$ & $\begin{array}{c}\text { 1Sigma }(68 \%) \\
\text { Cal. Age } \pm \text { Error } \\
\text { [years BP, BP }=1950 \mathrm{AD}] \\
\text { CALIB } 6.0(\text { Marine09) }\end{array}$ \\
\hline SO189-11MC (SMB) & UCI-78814 & G. sacculifer & 1280 & 15 & $828 \pm 40$ \\
\hline SO189-60MC (NB) & UCI-78815 & G. sacculifer & 625 & 15 & $273 \pm 15$ \\
\hline SO189-64MC (NB) & UCI-78816 & G. sacculifer & 1185 & 15 & $715 \pm 25$ \\
\hline SO189-87MC (SB) & UCI-78817 & G. sacculifer & 435 & 15 & $>1950 \mathrm{AD}$ \\
\hline SO189-97MC (SB) & UCI-78818 & G. sacculifer & -55 & 15 & $>1950 \mathrm{AD}$ \\
\hline GeoB 10008-4 (NMB) & UCI-78819 & G. sacculifer & 215 & 15 & $>1950 \mathrm{AD}$ \\
\hline GeoB 10010-1 (NMB) & UCI-78820 & G. sacculifer & -295 & 50 & $>1950 \mathrm{AD}$ \\
\hline GeoB 10016-2 (NB) & UCI-78821 & G. sacculifer & 640 & 20 & $281 \pm 20$ \\
\hline GeoB 10022-6 (NMB) & UCI-78822 & G. sacculifer & -335 & 15 & $>1950 \mathrm{AD}$ \\
\hline GeoB 10026-2 (NMB) & UCI-78823 & G. sacculifer & -180 & 15 & $>1950 \mathrm{AD}$ \\
\hline GeoB 10041-3 (JB) & UCI-78824 & G. sacculifer & -325 & 15 & $>1950 \mathrm{AD}$ \\
\hline GeoB 10049-5 (JB) & UCI-78825 & G. sacculifer & -230 & 15 & $>1950 \mathrm{AD}$ \\
\hline GeoB 10058-1 (JB) & UCI-78826 & G. sacculifer & -295 & 15 & $>1950 \mathrm{AD}$ \\
\hline GeoB 10063-5 (LB) & UCI-78827 & G. sacculifer & -350 & 15 & $>1950 \mathrm{AD}$ \\
\hline GeoB 10065-9 (LB) & OS-65991 & mixed planktonic & >modern & & $>1950 \mathrm{AD}$ \\
\hline GeoB 10069-4 (SS) & OS-65992 & mixed planktonic & $>$ modern & & $>1950 \mathrm{AD}$ \\
\hline
\end{tabular}

${ }^{a}$ Radiocarbon ages are converted to calendar ages using Marine 09 calibration [Hughen et al., 2004] of CALIB 6.0 software. Samples were measured at the Keck Carbon Cycle Accelerator Mass Spectrometry Laboratory, University of California, Irvine (UCI), and at the National Ocean Sciences Accelerator Mass Spectrometry Facility, Woods Hole (OS), respectively. SB: Simeulue Basin; NB: Nias Basin; NMB: Northern Mentawai Basin; SMB: Southern Mentawai Basin; JB: Java Basin; LB: Lombok Basin; SS: Savu Sea. Note that radiocarbon ages are converted to calendar ages assuming no deviation from the global ocean carbon reservoir of 400 years.

$\delta^{18} \mathrm{O}$ values for the species-specific disequilibrium effects would accordingly result in shallower or deeper apparent calcification depths of each species. However, most of the existing $\delta^{18} \mathrm{O}$-temperature equations have not considered the shell $\delta^{18} \mathrm{O}$ disequilibrium. Moreover, results from field and culture studies on the vital effect of planktic foraminifera differ significantly, or even contradict in terms of the sign (positive or negative disequilibrium) of the vital effect [see Niebler et al., 1999, and references therein]. For instance, the proposed $\delta^{18} \mathrm{O}$ disequilibrium for G. bulloides ranges between $-0.5 \%$ [Spero and Lea, 1996] and $+0.5 \%$ [Ganssen, 1983]. Since no data on seawater $\delta^{18} \mathrm{O}$ exist from the study area, we use in the following the measured shell $\delta^{18} \mathrm{O}$ of planktic foraminifera for calculating their apparent calcification depth, and later discuss possible vital effects on the inferred habitat depths.

\subsection{Alkenone Analyses}

[16] For alkenone analysis, samples were extracted with a Dionex Accelerated Solvent Extractor 200 in three cycles using dichloromethane as eluent. Extracts were dried under a stream of nitrogen, saponified with $0.5 \mathrm{ml} \mathrm{1-propanolic}$ $\mathrm{KOH}(5 \%)$ for $24 \mathrm{~h}$ at $20^{\circ} \mathrm{C}$ followed by a solid phase cleanup using silica gel columns to remove the $\mathrm{KOH}$. These purified extracts were analyzed by gas chromatography with a HP-6890 instrument equipped with a HP PTV Inlet on a DB-1 capillary column $(30 \mathrm{~m} * 0.25 \mathrm{~mm}$ i.d.; film thickness $0.25 \mu \mathrm{m})$ coupled to a flame ionization detector. Samples were injected splitless in dichloromethane using a cool injection program with solvent venting. Hydrogen was the

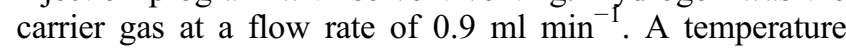
program of $2 \mathrm{~min}$. isothermal at $56^{\circ} \mathrm{C}, 56-150^{\circ} \mathrm{C}$ at $24^{\circ} \mathrm{C}$ $\mathrm{min}^{-1}, 150-320^{\circ} \mathrm{C}$ at $4.7^{\circ} \mathrm{C} \mathrm{min}^{-1}$ and $10 \mathrm{~min}$ isothermal was used, giving a good separation of all major compounds. Alkenones were identified by retention times. Quantification was performed relative to external calibration with $n-C_{36}$ alkane. The reproducibility of SST was better than 0.006
$\mathrm{U}_{37}^{\mathrm{K}^{\prime}}$ units or $0.2^{\circ} \mathrm{C}$. The ketone unsaturation index $\mathrm{U}_{37}^{\mathrm{K}^{\prime}}$ was converted to temperature according to Conte et al. [2006]:

$$
\mathrm{T}\left({ }^{\circ} \mathrm{C}\right)=-0.957+54.3\left(\mathrm{U}_{37}^{\mathrm{K}^{\prime}}\right)-52.9\left(\mathrm{U}_{37}^{\mathrm{K}^{\prime}}\right)^{2}+28.3\left(\mathrm{U}_{37}^{\mathrm{K}^{\prime}}\right)^{3}
$$

\subsection{Auxiliary Data}

[17] The $1^{\circ}$ by $1^{\circ}$ grid data of the World Ocean Atlas 2005 (WOA 05, http://www.nodc.noaa.gov) were used to estimate annual mean and boreal summer temperatures [Locarnini et al., 2006] and salinity [Antonov et al., 2006], and to calculate seawater $\delta^{18} \mathrm{O}$ at the studied sites (section 3.3.2). Annual mean and boreal summer vertical distributions of nitrate [Garcia et al., 2006] have been used as indicators for

Table 3. Comparison of Commonly Used Species-Specific Foraminiferal Temperature: The $\delta^{18} \mathrm{O}$ Relationship Using a Linear Approximation

\begin{tabular}{|c|c|c|c|}
\hline \multirow[b]{2}{*}{ Reference } & \multirow[b]{2}{*}{ Source } & \multicolumn{2}{|c|}{$\begin{array}{c}\mathrm{T}\left({ }^{\circ} \mathrm{C}\right)=\mathrm{a}+\mathrm{b} \\
\left(\delta^{18} \mathrm{O}_{\mathrm{C}}-\delta^{18} \mathrm{O}_{\mathrm{SW}}\right) \\
\end{array}$} \\
\hline & & a & $\mathrm{b}$ \\
\hline Shackleton [1974] & Uvigerina $s p$. & 16.9 & -4.0 \\
\hline $\begin{array}{l}\text { Bouvier-Soumagnac and } \\
\text { Duplessy [1985] }\end{array}$ & N. dutertrei & 10.5 & -6.58 \\
\hline \multirow{2}{*}{ Bemis et al. [1998] } & G. bulloides & 12.6 & -5.07 \\
\hline & O. universa & 14.9 & -4.80 \\
\hline Peeters [2000] & G. bulloides & 14.2 & -4.81 \\
\hline \multirow[t]{3}{*}{ Mulitza et al. [2003] } & G. ruber & 14.2 & -4.44 \\
\hline & G. sacculifer & 14.91 & -4.35 \\
\hline & G. bulloides & 14.62 & -4.70 \\
\hline Spero et al. [2003] & G. sacculifer & 12.0 & -5.67 \\
\hline \multirow[t]{5}{*}{ Farmer et al. [2007] } & G. ruber & 15.4 & -4.78 \\
\hline & G. sacculifer & 16.2 & -4.94 \\
\hline & N. dutertrei & 14.6 & -5.09 \\
\hline & P. obliquiloculata & 16.8 & -5.22 \\
\hline & G. tumida & 13.1 & -4.95 \\
\hline
\end{tabular}


nutrient availability. However, most of the $1^{\circ}$ by $1^{\circ}$ grids of the WOA 05 were from the open ocean further offshore and thus, did not capture the nearshore upper water column dynamics at the sampling sites. Another limitation of using WOA 05 data is that several surface sample sites, particularly samples from the SB, NB, and NMB, are situated within only one WOA 05 grid box. These restrictions hamper a detailed, site-specific study, especially in the case of seawater $\delta^{18} \mathrm{O}$ calculation and the habitat depth estimation of planktic foraminifera. On the other hand, local effects such as bioturbation and different ages of the surface samples might bias the geochemical proxies and their relation to the modern hydrographic data. We therefore calculated also mean values for each basin in order to reduce local effects and deviation of the geochemical proxies from the WOA 05 data. In summary, the insufficient coverage of the study area by the WOA 05 data sets remains the main limitation for a precise calibration of the surface data to the modern hydrographic data.

\section{Results}

\subsection{Radiocarbon Ages}

[18] Assuming that surface samples with an intact fluffy layer represent modern conditions, only multicore top samples without a surface fluffy layer were selected for radiocarbon measurements on G. sacculifer in order to estimate the oldest possible ages of the surface samples in the study area. Nonetheless, the results reveal modern ages for the selected surface samples (Table 2). Notable are the three surface samples from the Nias Basin (NB) that show older ages than in the other basins. We attribute this to lower sedimentation rates on the outer slope (GeoB 10016-2), stronger bioturbation on the shelf (SO189-64MC, $69 \mathrm{~m}$ water depth), and possibly a combination of both processes (SO189-60MC). Therefore, we infer that other surface samples from the NB still represent present-day conditions. Low sedimentation rates and stronger bioturbation might also be responsible for the oldest measured age of $\sim 800$ years reported from the southern Mentawai Basin (SO189-11MC).

\subsection{Shell $\delta^{18} \mathrm{O}$-Derived Calcification Depths}

\subsubsection{G. ruber Sensu Stricto and Sensu Lato}

[19] Average shell $\delta^{18} \mathrm{O}$ values of $G$. ruber s.s. are indistinguishable in the $\mathrm{SB}, \mathrm{NB}$, and the $\mathrm{NMB}$ (around $-3.15 \%$ ), and in the JB, LB, and the SS (around $-2.9 \%$, Table 1), respectively. Average value in the SMB ( - $3.0 \%$ ) lies between those for the other basins. Average shell $\delta^{18} \mathrm{O}$ values of $G$. ruber s.l. are very similar to those of $G$. ruber s. $\mathrm{s}$. in the $\mathrm{SB}, \mathrm{NB}, \mathrm{NMB}$, and the $\mathrm{SMB}$, but on average $0.14 \%$ lighter in the JB, LB, and the SS (Table 1).
[20] Calcification depths inferred from G. ruber s.s. and $G$. ruber s.l. shell $\delta^{18} \mathrm{O}$ suggest comparable habitat depths for both species regardless of the equation used (Figure 3). Average calcification depths of $G$. ruber s.s. are slightly deeper in the SB and NB, where a thick mixed-layer exists throughout the year, and slightly shallower in the upwelling areas of JB, LB and SS (Figures 3a-3d). In contrast, average calcification depth of $G$. ruber s.l. does not change in different basins (Figures 3e-3h). However, the range of the estimated calcification depths from the individual measurements is larger than that of $G$. ruber s.s., with three samples appearing as outliers, showing values above $-2.4 \%$ (GeoB 10050-1) and below $-3.7 \%$ (SO189-89MC and 97MC).

\subsubsection{G. sacculifer and $G$. bulloides}

[21] Average shell $\delta^{18} \mathrm{O}$ values of $G$. sacculifer are similar in the $\mathrm{SB}, \mathrm{NB}, \mathrm{NMB}$, and the SMB (around $-2.75 \%$ ), and between $-2.5 \%$ and $-2.6 \%$ in the JB, LB, and the SS (Table 1). Average $\delta^{18} \mathrm{O}$ values of $G$. bulloides are lighter in the non-upwelling environments of the SB, NB, and the NMB (between $-3.05 \%$ and $-3.09 \%$ ), and heavier in the upwelling areas of the SMB, JB, LB, and the SS (between $-2.5 \%$ and $-2.8 \%$, Table 1$)$. Shell $\delta^{18} \mathrm{O}$-derived average calcification depth of $G$. sacculifer varies between $20 \mathrm{~m}$ and $75 \mathrm{~m}$, depending on the $\delta^{18} \mathrm{O}$ :temperature equation applied (Figures $4 \mathrm{a}-4 \mathrm{~d}$ ). Shallowest calcification depths between $20 \mathrm{~m}$ and $50 \mathrm{~m}$ are obtained when using the Farmer et al. [2007] equation (Figure 4b), while the Mulitza et al. [2003] equation suggests deepest calcification depths of about $75 \mathrm{~m}$ for $G$. sacculifer (Figure 4c). The species-specific equation proposed by Spero et al. [2003] suggests calcification depths between $50 \mathrm{~m}$ and $75 \mathrm{~m}$ (Figure 4a), while the equation proposed by Shackleton [1974] implies slightly shallower calcification depths closer to the $50 \mathrm{~m}$ isoline (Figure 4d). In general, calcification depths of G. sacculifer do not change significantly in different basins, except for Farmer et al. [2007] and Shackleton [1974] equations that suggest a slightly deeper calcification depth in the Simeulue and Nias Basins, similar to the inferred calcification depths for $G$. ruber s.s. (Figures 3a-3d).

[22] For G. bulloides, estimation of the expected equilibrium $\delta^{18} \mathrm{O}$ of calcite is based on boreal summer temperature and salinity data of WOA 05 (solid lines in Figure 4e-4h). This inference is based on the analyses of a sediment trap time series beneath the upwelling area off S Java by Mohtadi et al. [2009] showing that $\sim 90 \%$ of the total flux of G. bulloides larger than $250 \mu \mathrm{m}$ occurs during the boreal summer season. Hence, the strong seasonality of $G$. bulloides needs to be considered when estimating its calcification depth in the upwelling areas of SMB, JB, LB, and the SS. In the other basins, characterized by non-upwelling environments

Figure 3. Shell $\delta^{18} \mathrm{O}$-based calcification temperatures and habitat depth estimates for (a-d) G. ruber s.s. and (e-h) G. ruber s.l. in the tropical eastern Indian Ocean. Solid lines indicate the expected upper water column $\delta^{18} \mathrm{O}$ of calcite in the study area, averaged for different depths $(0-75 \mathrm{~m})$ using the WOA 05 annual mean temperature [Locarnini et al., 2006] and salinity [Antonov et al., 2006] data, salinity: $\delta^{18} \mathrm{O}_{\mathrm{SW}}$ relationship of Morimoto et al. [2002], and species-specific $\delta^{18} \mathrm{O}$ :temperature equations for each panel. Gray dots are measured shell $\delta^{18} \mathrm{O}$ values of the entire surface samples, black dots are average values for each basin. Average values represent the following basins from left to right: Simeulue Basin, Nias Basin, Northern Mentawai Basin, Southern Mentawai Basin, Java Basin, Lombok Basin, and the Savu Sea. Shaded envelopes indicate the error range calculated from the combined analytical error of the measured and the expected $\delta^{18} \mathrm{O}$ of calcite, and the standard deviation of their difference. 

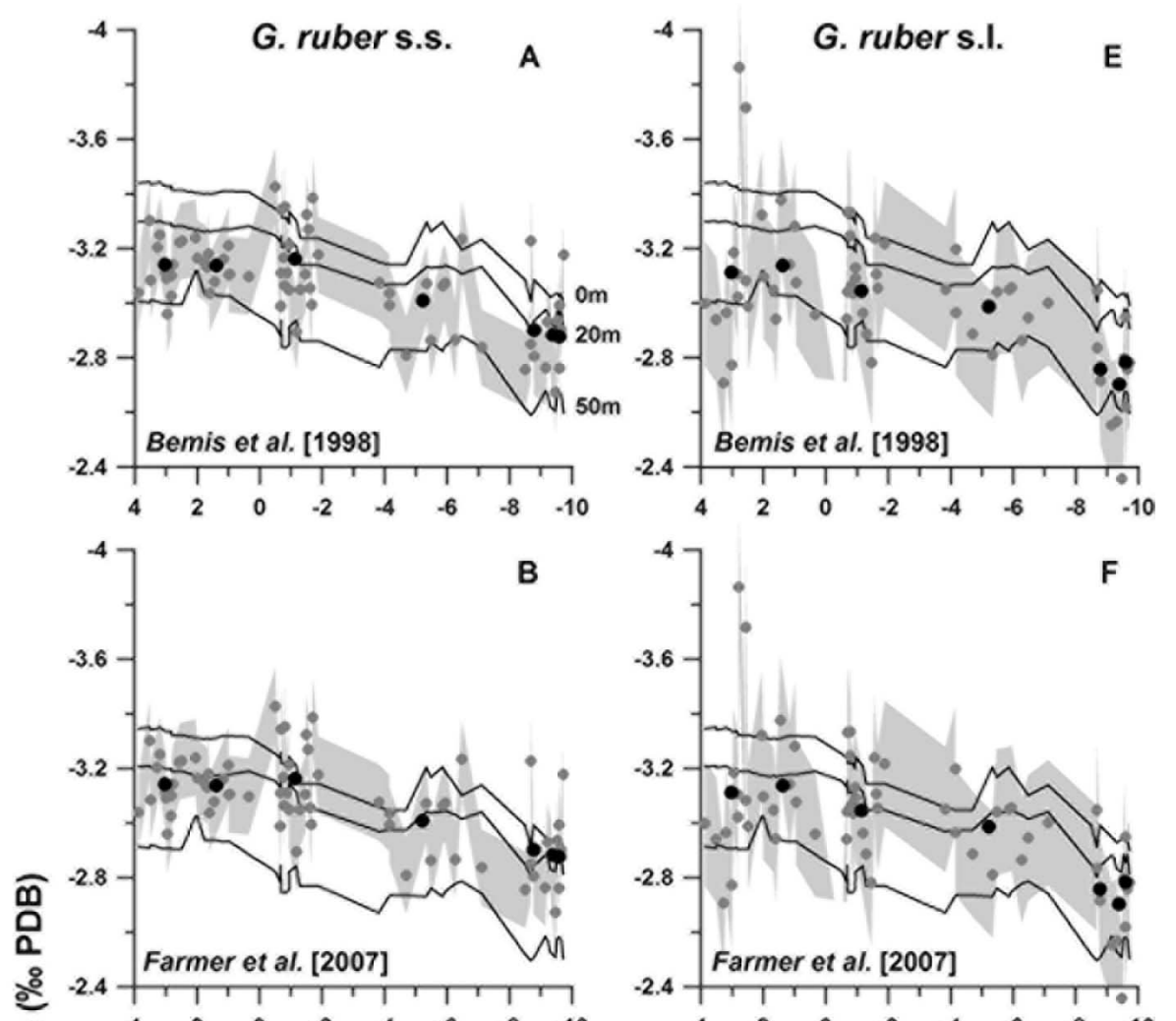

$F$
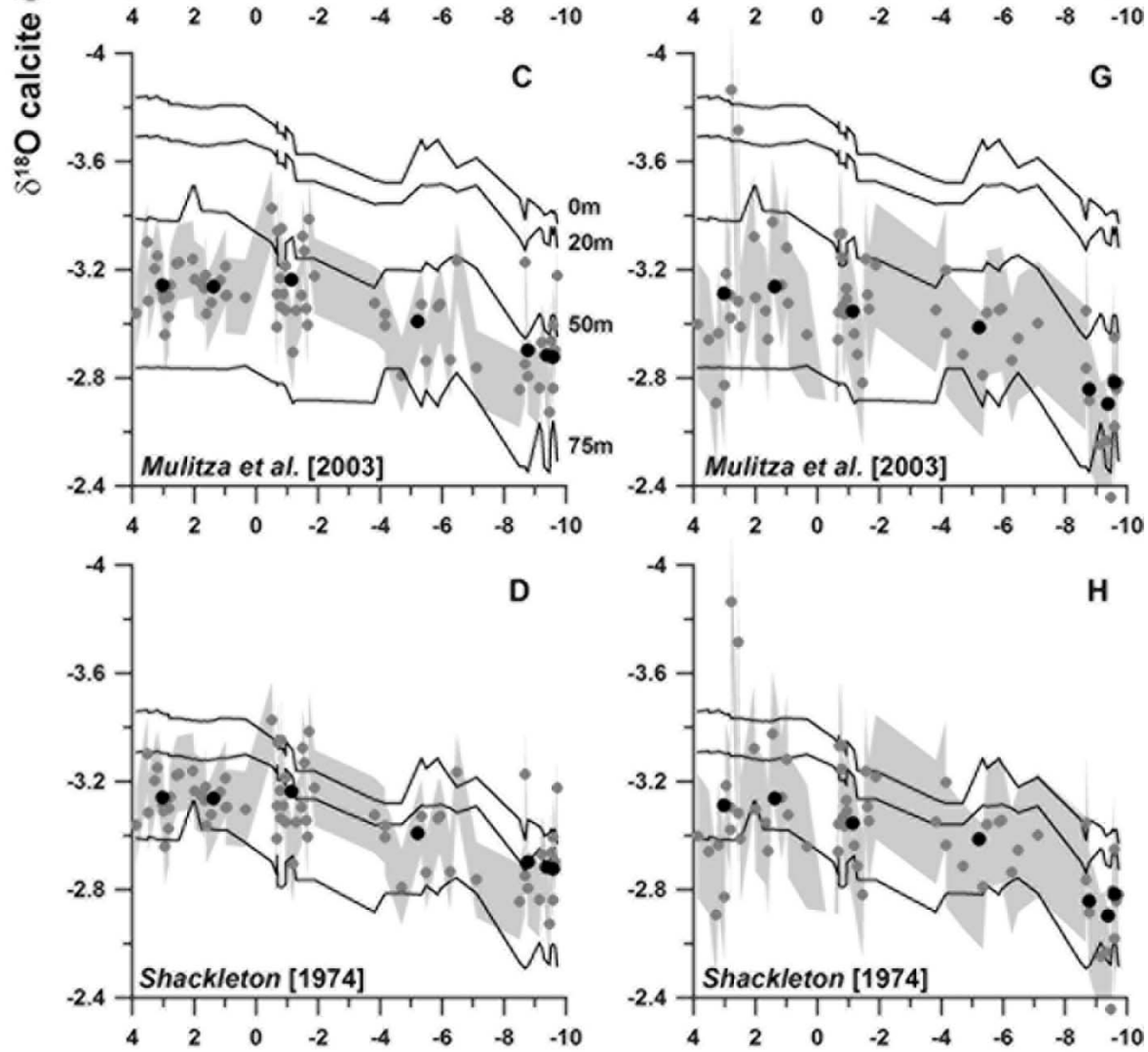

\section{Latitude $\left({ }^{\circ} \mathrm{N}\right)$}

Figure 3 

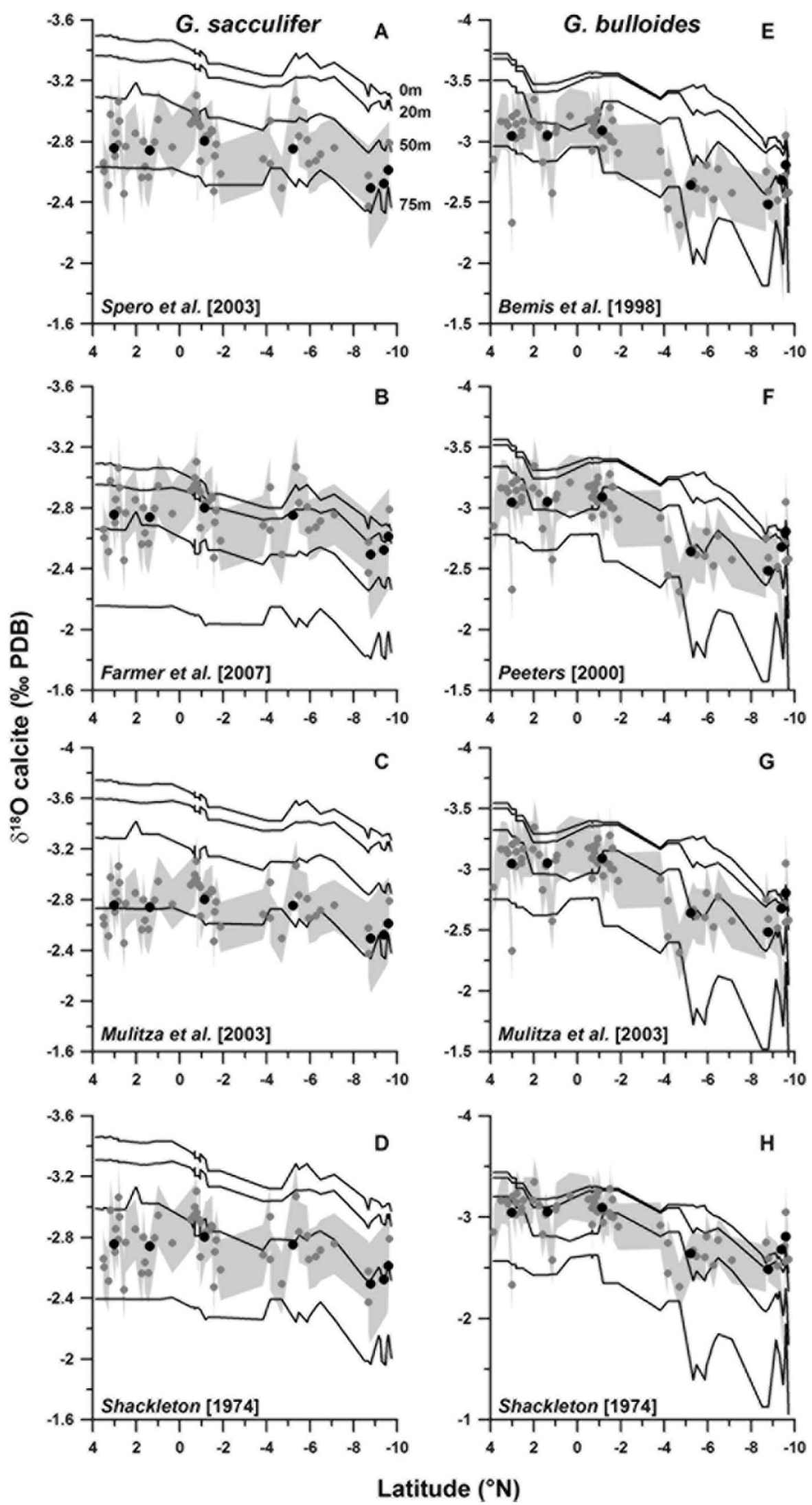

Figure 4. Shell $\delta^{18} \mathrm{O}$-based calcification temperatures and habitat depth estimates for (a-d) G. sacculifer and (e-h) G. bulloides in the tropical eastern Indian Ocean. Shaded envelops, solid lines and dots are as in Figure 3, except the solid lines in G. bulloides panels (Figures $4 \mathrm{e}-4 \mathrm{~h}$ ) representing boreal summer values. Note the different scales for each panel. 
(SB, NB, NMB), annual mean and summer temperatures and salinities do not differ significantly (Figures S1 and S2), enabling us to apply summer values for G. bulloides in the entire study area.

[23] Shell $\delta^{18} \mathrm{O}$-derived average calcification depths of G. bulloides range around the $50 \mathrm{~m}$ isoline and tend to decrease in the JB, LB and the SS, regardless of the equation used (Figures $4 \mathrm{e}-4 \mathrm{~h}$ ). Calcification depths are slightly deeper when applying the Bemis et al. [1998] equation (Figure 4e), and shallower when using the Shackleton [1974] equation (Figure 4h). The two equations proposed by Mulitza et al. [2003] and Peeters [2000] are almost identical and therefore, the resulting calcification depths for G. bulloides are similar for different basins (Figures $4 \mathrm{f}$ and $4 \mathrm{~g}$ ).

\subsubsection{N. dutertrei, P. obliquiloculata, and G. tumida}

[24] Average shell $\delta^{18} \mathrm{O}$ values of $N$. dutertrei range between about $-2.0 \%$ and $-2.1 \%$ in the SB, NB, NMB, and the SMB, and between $-1.6 \%$ and $-1.8 \%$ in the JB, LB, and the SS, respectively (Table 1 ). Average shell $\delta^{18} \mathrm{O}$ values of P. obliquiloculata range between $-2.3 \%$ and $-2.4 \%$ in the $\mathrm{SB}, \mathrm{NB}$, and the $\mathrm{NMB}$, and between about $-1.4 \%$ and $-1.7 \%$ in the JB, LB, and the SS, respectively (Table 1). Average value for the SMB lies in between, at about $-1.9 \%$. Average shell $\delta^{18} \mathrm{O}$ values of $G$. tumida differ significantly for different basins, ranging between about $-0.4 \%$ and $0.5 \%$, which might be due to the small amount of data on this species, or different amounts of secondary calcite. $G$. tumida is absent in the surface samples from the SB, and only present in one (two) surface sample(s) from the NB (NMB) suggesting the preference of this species for the nutrient-rich subsurface waters beneath the upwelling areas in the southern part of the study area (Table 1).

[25] Estimation of the expected equilibrium $\delta^{18} \mathrm{O}$ of calcite for P. obliquiloculata, $N$. dutertrei, and G. tumida is based on boreal summer temperature and salinity data of WOA 05 , due to their preferred seasonality similar to $G$. bulloides [Mohtadi et al., 2009]. Shell $\delta^{18} \mathrm{O}$-derived average calcification depths of $N$. dutertrei show insignificant changes by applying different equations and vary between $75 \mathrm{~m}$ and $100 \mathrm{~m}$ in the study area (Figures $5 \mathrm{a}-5 \mathrm{c}$ ). Calcification depths are slightly shallower in the SMB ( 75 m) and somewhat deeper in the SB. Estimated average calcification depths for $P$. obliquiloculata are similar to those of $N$. dutertrei in the $\mathrm{SB}, \mathrm{NB}, \mathrm{NMB}$, and the $\mathrm{SMB}$, and slightly deeper in the JB, LB, and the SS when applying the Shackleton [1974] and Bouvier-Soumagnac and Duplessy [1985] equations (Figures 5d and 5f). In general, the Farmer et al. [2007] equation implies shallower average calcification depths between $50 \mathrm{~m}$ and $75 \mathrm{~m}$ in the SB, NB, $\mathrm{NMB}$, and the SMB, and deeper calcification depths below $75 \mathrm{~m}$ in the JB, LB, and the SS (Figure 5e). Shell $\delta^{18} \mathrm{O}-$ derived average calcification depths of $G$. tumida lie between $100 \mathrm{~m}$ and $150 \mathrm{~m}$ when applying the $\delta^{18} \mathrm{O}$ :temperature equation of Shackleton [1974], and at $\sim 150 \mathrm{~m}$ when using the species-specific equation of Farmer et al. [2007] (Figures 5g and $5 \mathrm{~h}$ ).

\subsection{Shell $\mathrm{Mg} / \mathrm{Ca}$ Values and Alkenone-Derived SST}

[26] Of all the planktic foraminifera measurements, shell $\mathrm{Mg} / \mathrm{Ca}$ values were unrealistically high in one sample from the SB (SO189-112MC), and two samples from the NB (SO189-64MC and SO189-65MC, see Table 1). These samples were retrieved from shallow waters at or shallower than $80 \mathrm{~m}$ close to the shore, offshore two (small) river mouths. Since there are no anomalous values in the $\delta^{18} \mathrm{O}$, $\mathrm{Fe} / \mathrm{Ca}$ or $\mathrm{Al} / \mathrm{Ca}$ of these samples, the high $\mathrm{Mg} / \mathrm{Ca}$ values cannot easily be explained by increased freshwater input, inorganic calcite precipitation, dissolution or insufficient cleaning of the samples. Likewise, examination of the planktic foraminiferal tests does not show any significant diagenetic overprint. To this end, we do not have any sound explanation of these anomalous values and exclude these samples from calculation of average $\mathrm{Mg} / \mathrm{Ca}$ in these basins.

[27] Average shell $\mathrm{Mg} / \mathrm{Ca}$ of G. ruber s.s. and G. ruber s.l. shows higher values in the $\mathrm{SB}, \mathrm{NB}, \mathrm{NMB}$, and the SMB, and decreases significantly in the JB, LB, and the SS (Table 1). Highest average $\mathrm{Mg} / \mathrm{Ca}$ value occurs in the NB $(\sim 6 \mathrm{mmol}$ $\mathrm{mol}^{-1}$ ). Average $\mathrm{Mg} / \mathrm{Ca}$ values of $G$. ruber s.s. and $G$. ruber s.l. are similar in different basins, except for the LB, where G. ruber s.l. value is on average $0.45 \mathrm{mmol} \mathrm{mol}^{-1}$ lower than the G. ruber s.s. value.

[28] Likewise, average shell $\mathrm{Mg} / \mathrm{Ca}$ of $\mathrm{G}$. sacculifer shows higher values in the SB, NB, NMB, and the SMB, and decreases significantly in the JB, LB, and the SS (Table 1). Highest average $\mathrm{Mg} / \mathrm{Ca}$ value occurs in the NB ( 4.7 mmol $\left.\mathrm{mol}^{-1}\right)$. Average shell $\mathrm{Mg} / \mathrm{Ca}$ of $\mathrm{G}$. bulloides is high in the $\mathrm{SB}, \mathrm{NB}$, and the NMB $\left(>7.6 \mathrm{mmol} \mathrm{mol}^{-1}\right)$ and decreases considerably to values $<6.4 \mathrm{mmol} \mathrm{mol}^{-1}$ in the upwelling areas of the SMB, JB, and the LB (Table 1). The SS is represented by only one sample with a relatively high $\mathrm{Mg} / \mathrm{Ca}$ value of $\sim 7 \mathrm{mmol} \mathrm{mol}^{-1}$.

[29] Shell $\mathrm{Mg} / \mathrm{Ca}$ values of $P$. obliquiloculata and $N$. dutertrei show a decrease from higher values in the nonupwelling areas of the $\mathrm{SB}, \mathrm{NB}$, and the NMB $(\geq 3 \mathrm{mmol}$ $\mathrm{mol}^{-1}$ ) to lower values in the upwelling areas of the SMB, $\mathrm{JB}, \mathrm{LB}$, and the SS $\left(\leq 2.75 \mathrm{mmol} \mathrm{mol}^{-1}\right.$, Table 1). This pattern can also be observed for G. tumida, although only three samples exist from the non-upwelling basins.

[30] Average alkenone-based SST estimates for different basins do not vary considerably $\left(28^{\circ} \mathrm{C} \pm 0.4^{\circ} \mathrm{C}\right.$, Table 1$)$, with lowest (highest) average SST of $\sim 27.8^{\circ} \mathrm{C}\left(28.4^{\circ} \mathrm{C}\right)$ recorded in the JB (NB). Moreover, SST estimates are remarkably similar within the different basins and do not deviate by more than $0.5^{\circ} \mathrm{C}$ from the observed average SST for each basin, except for one sample (SO189-31MC) recording the lowest $\operatorname{SST}\left(27^{\circ} \mathrm{C}\right)$ in the study area.

\section{Discussion}

\section{1. $\mathrm{Mg} / \mathrm{Ca}$ Versus $\delta^{18} \mathrm{O}$-Derived Calcification Depths/Temperatures}

[31] In the following, calcification depths are considered to be between $20 \mathrm{~m}$ and $50 \mathrm{~m}$ for $G$. ruber s.s., at $50 \mathrm{~m}$ for G. ruber s.l., G. sacculifer, and G. bulloides, at $75 \mathrm{~m}$ for $N$. dutertrei and P. obliquiloculata, and at $100 \mathrm{~m}$ for $G$. tumida. The deeper habitat inferred for various species by applying the plankton tow and culture based equations of Mulitza et al. [2003, Figures 3c, 3g, and 4c] and Spero et al. [2003, Figure 4a] might be a result of generally higher $\delta^{18} \mathrm{O}$ values recorded by surface samples. Our results agree with previous studies suggesting habitat depths of $G$. ruber s.s., G. ruber s.l., G. sacculifer and G. bulloides within the mixed-layer, and of $N$. dutertrei, P. obliquiloculata, and G. tumida within the thermocline [e.g., Fairbanks and 

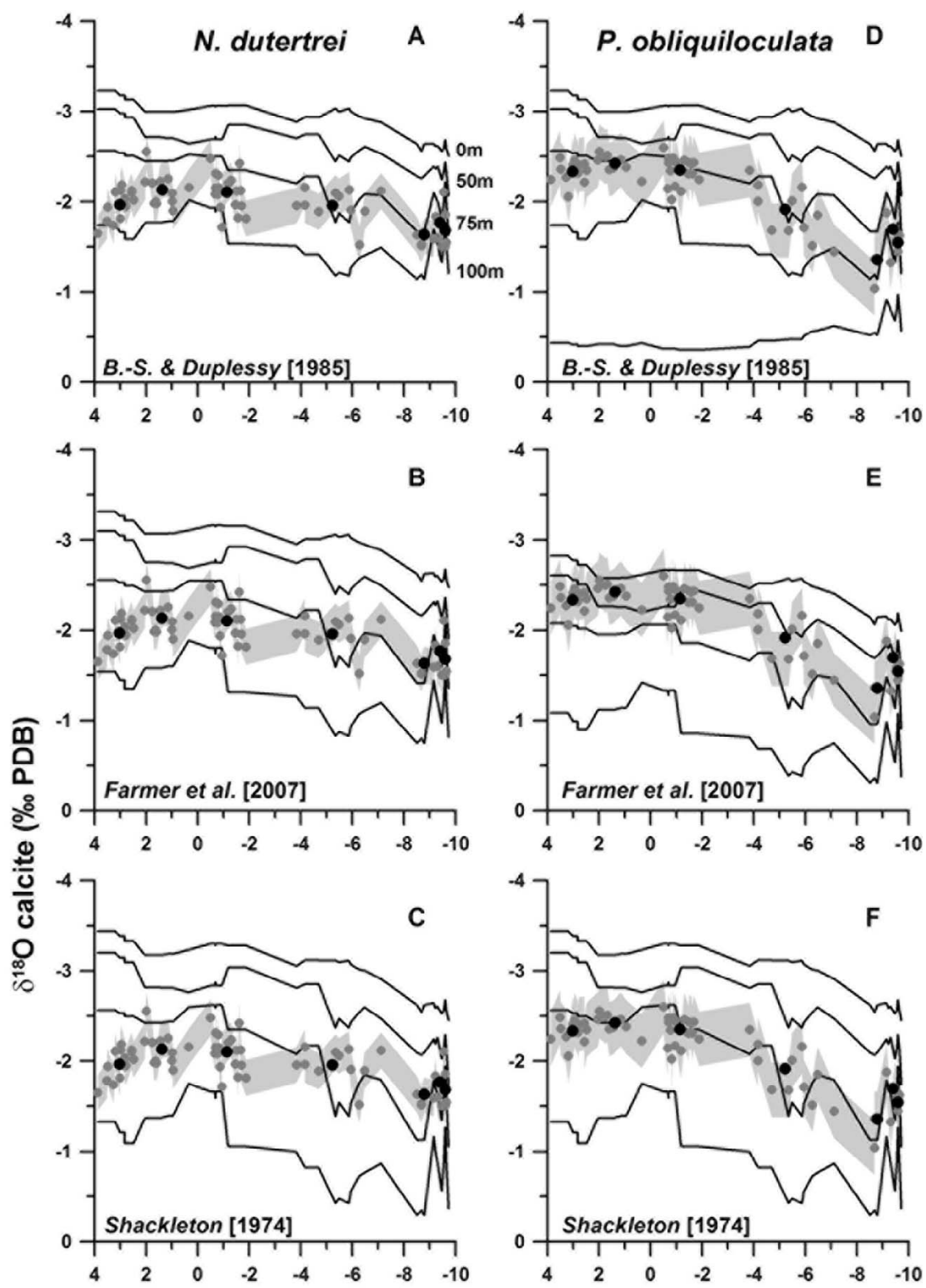

G. tumida
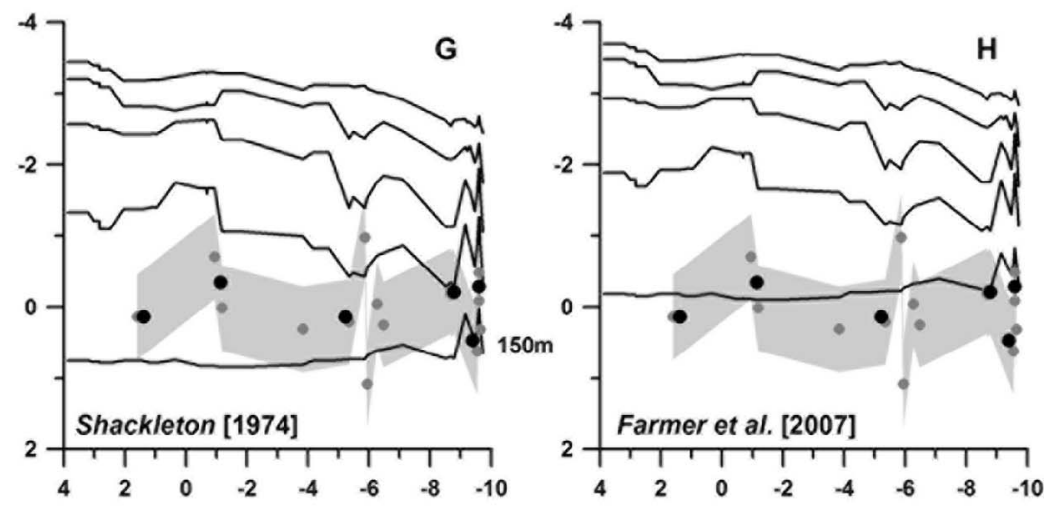

Latitude $\left({ }^{\circ} \mathrm{N}\right)$

Figure 5. Shell $\delta^{18} \mathrm{O}$-based calcification temperatures and habitat depth estimates for $(\mathrm{a}-\mathrm{c}) \mathrm{N}$. dutertrei, (d-f) P. obliquiloculata, and ( $\mathrm{g}$ and $\mathrm{h})$ G. tumida in the tropical eastern Indian Ocean. Shaded envelops, solid lines and dots are as in Figure 3, except that the solid lines represent boreal summer values. 
A) G. ruber s.s.

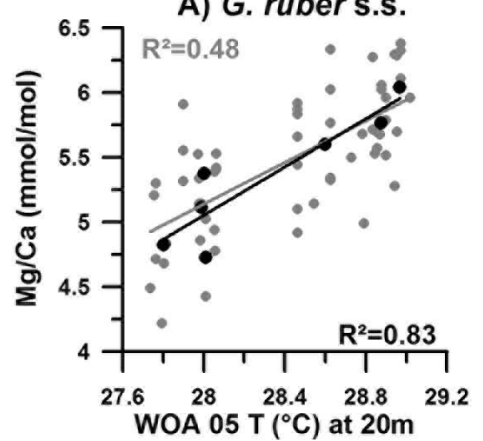

D) G. bulloides

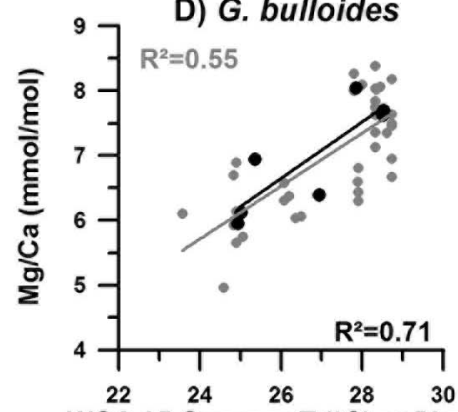

WOA 05-Summer $\mathrm{T}\left({ }^{\circ} \mathrm{C}\right)$ at $50 \mathrm{~m}$
B) G. ruber s.I.

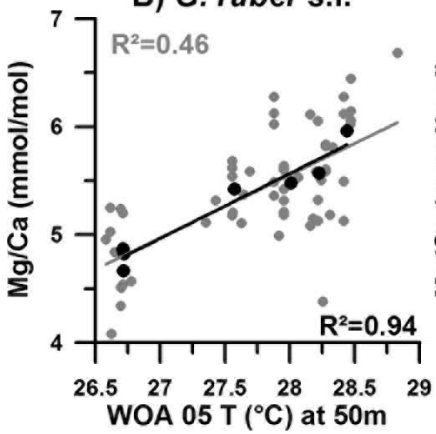

E) $P$. obliquiloculata

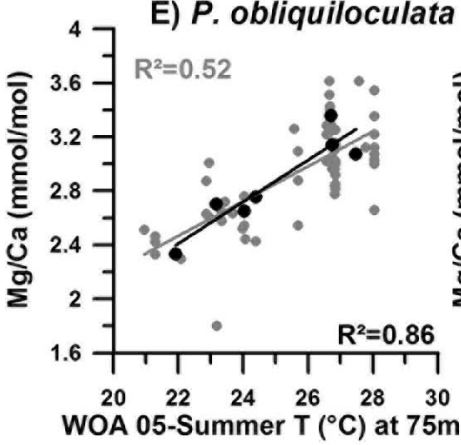

C) G. sacculifer

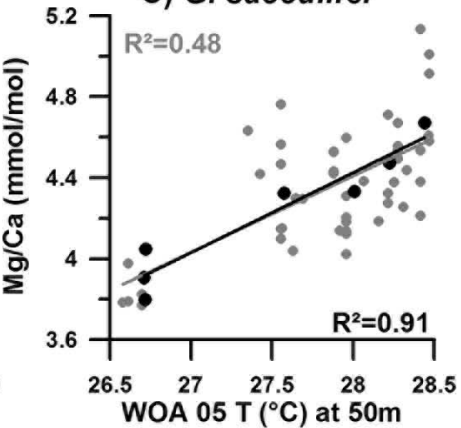

F) N. dutertrei

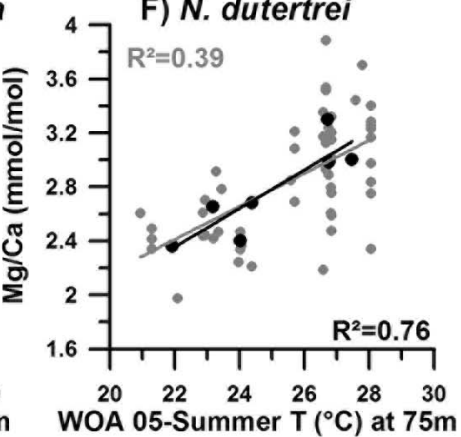

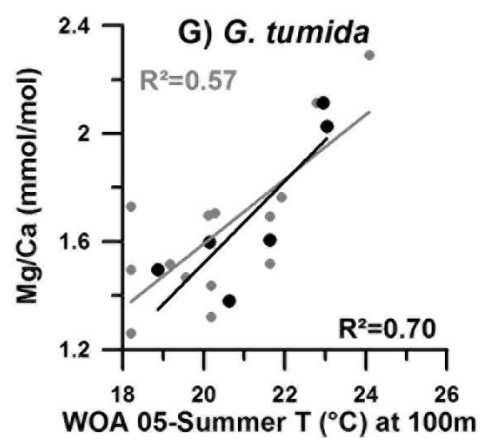

Figure 6. Relationship between shell $\mathrm{Mg} / \mathrm{Ca}$ ratio and the calcification temperatures of various planktic foraminiferal species in the study area. Gray: the entire data sets; black: average values for each basin. Temperatures are taken from the WOA 05 data set, at depths that correspond to the estimated calcification depth of each species (see Figures 3-5). $\mathrm{Mg} / \mathrm{Ca}$ values are plotted versus annual mean temperatures at (a) $20 \mathrm{~m}$ and (b and c) $50 \mathrm{~m}$, and versus summer temperatures at (d) $50 \mathrm{~m}$, (e and f) $75 \mathrm{~m}$, and (g) $100 \mathrm{~m}$, respectively.

Wiebe, 1980; Fairbanks et al., 1982; Peeters, 2000; Field, 2004; Kuroyanagi and Kawahata, 2004; Farmer et al., 2007].

[32] Shell $\mathrm{Mg} / \mathrm{Ca}$ ratios of all species show a significant, linear relationship to temperatures from the WOA 05 data at depths that correspond to the estimated calcification depth of each species (Figure 6). Since salinities in the upper water column of the study area are lower than 35 psu (Figure S2), a positive salinity effect on shell $\mathrm{Mg} / \mathrm{Ca}$ ratios [Arbuszewski et al., 2010] can be neglected. The large scatter in the data (gray dots in Figure 6) might be due to the (a) relatively narrow temperature range for each species, (b) different amount of encrustation [e.g., Schmidt and Mulitza, 2002], (c) different genetic types [e.g., Darling et al., 2003], (d) different ages of the surface samples, (e) a limited coverage of local hydrography by the WOA 05 data, both spatially and vertically, and (f) interannual variability in local hydrography caused by ENSO or IOD that cannot be resolved in our core top study. Therefore, it is not surprising that average values for each basin (black dots in Figure 6) show improved correlation coefficients $\left(\mathrm{R}^{2}\right)$ at or greater than 0.7 for all species by reducing the above mentioned uncertainties, although a larger $\mathrm{R}^{2}$ is also a result of fewer data points. It should be noted that for $G$. ruber s.s., G. bulloides, and G. tumida, correlation coefficients between $\mathrm{Mg} / \mathrm{Ca}$ and WOA 05 temperatures are also significant at adjacent depths due to the fact that calcification of planktic foraminifera and hence, incorporation of $\mathrm{Mg}$ in their calcite shell, occur within a depth range, rather than at a fixed depth (see Figure S3 and discussion below).

[33] In face of a small temperature range for each species in the study area, $\mathrm{Mg} / \mathrm{Ca}$-temperature relationship could be 
expressed as a linear function (Figure 6). However, previous studies showed that shell $\mathrm{Mg} / \mathrm{Ca}$ in planktic foraminifera increases exponentially with temperature [e.g., Elderfield and Ganssen, 2000; Dekens et al., 2002; Anand et al., 2003; McConnell and Thunell, 2005; Cléroux et al., 2008; Regenberg et al., 2009]. The species-specific Mg/Ca-temperature exponential relationships from this study (Figure 7 , black dots and lines) fit within the range of previously published equations, although they occur at the warm end of the existing calibrations (Figure 7, gray lines). The only exception is the $\mathrm{Mg} / \mathrm{Ca}$-temperature relationship of $\mathrm{G}$. tumida that shows a comparable slope with the Rickaby and Halloran [2005] equation, but a different intercept (Figure 7g), which might be due to the much shallower inferred habitat of this species in the study area, or to the different size-fractions used in the other studies (300-355 $\mu \mathrm{m}$ [Rickaby and Halloran, 2005] and 355-400 $\mu \mathrm{m}$ [Regenberg et al., 2009]). We therefore calculated a regional $\mathrm{Mg} / \mathrm{Ca}$-temperature calibration for G. tumida:

$$
\mathrm{Mg} / \mathrm{Ca}=0.41 \exp \left(0.068^{*} T\right)
$$

[34] For all the other species, the existing $\mathrm{Mg} / \mathrm{Ca}-$ temperature calibrations can be used for the eastern equatorial Indian Ocean. For $G$. ruber s.s., G. ruber s.1., and $G$. sacculifer the regional calibrations fit best to the equations proposed by Anand et al. [2003] for the same size-fractions used in this study $(\mathrm{Mg} / \mathrm{Ca}=0.34 \exp (0.102 * \mathrm{~T})$ and $\mathrm{Mg} / \mathrm{Ca}=$ $0.38 \exp (0.09 * \mathrm{~T})$ for $\mathrm{G}$. ruber, Figures $7 \mathrm{a}$ and $7 \mathrm{~b}, \mathrm{Mg} / \mathrm{Ca}=$ $0.347 \exp \left(0.09^{*} \mathrm{~T}\right)$ for $G$. sacculifer without sac, Figure $\left.7 \mathrm{c}\right)$. Regional $\mathrm{Mg} / \mathrm{Ca}$-temperature relationship of $\mathrm{G}$. bulloides is best explained by the equation of Elderfield and Ganssen [2000] $\left(\mathrm{Mg} / \mathrm{Ca}=0.81 \exp \left(0.081^{*} \mathrm{~T}\right)\right)$. For $N$. dutertrei, the regional calibration fits best to the equation proposed by Regenberg et al. [2009] $\left(\mathrm{Mg} / \mathrm{Ca}=0.65 \exp \left(0.065^{*} \mathrm{~T}\right)\right.$, Figure 7e). Finally, regional $\mathrm{Mg} / \mathrm{Ca}$-temperature relationship of $P$. obliquiloculata matches best to the equation for deepdwelling foraminifera proposed by Cléroux et al. [2008] $\left(\mathrm{Mg} / \mathrm{Ca}=0.78 \exp \left(0.052^{*} \mathrm{~T}\right)\right.$, Figure $\left.7 \mathrm{f}\right)$.

[35] As mentioned above, $\delta^{18} \mathrm{O}$-disequilibrium effect on the calculation of apparent calcification depths of planktic foraminifera might also impact their $\mathrm{Mg} / \mathrm{Ca}$-temperature relationships. Correcting the measured $\delta^{18} \mathrm{O}$ values for a range of disequilibrium values suggested for $G$. sacculifer, N. dutertrei, and P. obliquiloculata [see Niebler et al., 1999; Regenberg et al., 2009, and references therein] would increase their calcification depths, but decrease significantly $(0.1-0.3)$ the correlation coefficient of their $\mathrm{Mg} / \mathrm{Ca}$-temperature calibration. This finding, in accordance with results of Regenberg et al. [2009], justifies the application of the disequilibrium-uncorrected calibration for these species. There is no disequilibrium effect reported for G. ruber s.l. and
$G$. tumida. Correcting the measured $\delta^{18} \mathrm{O}$ values for a range of disequilibrium values suggested for $G$. ruber s.s. ( $G$. bulloides) would increase (increase or decrease) its calcification depth, while the correlation coefficient of the $\mathrm{Mg} / \mathrm{Ca}$-temperature calibration remains high (Figure S3). This might be a result of a bimodal vertical distribution of these species in the water column [e.g., Peeters et al., 2002; Kuroyanagi and Kawahata, 2004] due to different hydrologic conditions in the study area (upwelling and nonupwelling areas), or different genotypes of these species in sediment samples [e.g., Darling et al., 2003]. In spite of these possible effects, the water depths with a significant $\mathrm{Mg} / \mathrm{Ca}$-temperature correlation coefficient for these species match the range of their $\delta^{18} \mathrm{O}$-derived calcification depths (20-50 $\mathrm{m}$ for $G$. ruber and 20-75 $\mathrm{m}$ for G. bulloides, Figures $3 \mathrm{a}-3 \mathrm{~d}$ and $4 \mathrm{e}-4 \mathrm{~h}$ ), justifying the application of the disequilibrium-uncorrected calibration for these species. Nonetheless, future field studies on both planktic foraminifera and local hydrography are imperative in order to assess the $\delta^{18} \mathrm{O}$-disequilibrium effect of planktic foraminifera, and to better calculate their apparent calcification depth.

\subsection{Use of Temperature Proxies for Reconstructing Upper Water Column Hydrology}

[36] Conversion of the $\mathrm{Mg} / \mathrm{Ca}$ values to temperatures using the species-specific calibrations that match the apparent calcification depths of planktic foraminifera reveals a relatively consistent picture in the study area (Figure 8). In the non-upwelling basins of $\mathrm{SB}, \mathrm{NB}$, and the $\mathrm{NMB}, \mathrm{Mg} / \mathrm{Ca}$ temperatures of the surface-dwelling species $G$. ruber s.s., G. ruber s.l., G. sacculifer, and G. bulloides reflect mixedlayer temperatures between $0 \mathrm{~m}$ and $50 \mathrm{~m}$ at or above $28^{\circ} \mathrm{C}$, whereby the succession of these species reflects decreasing (increasing) temperatures (habitat depths). Alkenone-based temperatures appear to match $\mathrm{Mg} / \mathrm{Ca}$ temperatures of $G$. sacculifer, also reflecting mixed-layer temperatures in these basins. Since there are no significant seasonal changes in the mixed-layer conditions of these basins, our sediment surface data suggest that these proxies can be used to reconstruct past mixed-layer conditions of the eastern equatorial Indian Ocean, from $\sim 4^{\circ} \mathrm{N}$ to $\sim 4^{\circ} \mathrm{S}$. $\mathrm{Mg} / \mathrm{Ca}$ temperatures of $P$. obliquiloculata and $N$. dutertrei reflect upper thermocline temperatures at $\sim 70 \mathrm{~m}\left(26^{\circ} \mathrm{C}-28^{\circ} \mathrm{C}\right)$ and $\sim 100 \mathrm{~m}\left(23^{\circ} \mathrm{C}-\right.$ $25^{\circ} \mathrm{C}$ ), respectively. Despite the sparse data of $G$. tumida from these basins, it appears that this species records nearly the same temperatures as $N$. dutertrei, at $\sim 100 \mathrm{~m}$ water depth $\left(23^{\circ} \mathrm{C}-24^{\circ} \mathrm{C}\right)$. Accordingly, these three species can be used to reconstruct the upper thermocline conditions in the eastern Indian Ocean, from $\sim 4^{\circ} \mathrm{N}$ to $\sim 4^{\circ} \mathrm{S}$.

[37] In the southern basins of SMB, JB, LB, and the SS, calibrated temperatures based on shell $\mathrm{Mg} / \mathrm{Ca}-$ and calcification depth of planktic foraminifera suggest that $G$. ruber s.s., G. ruber s.l., and G. sacculifer reflect annual mean mixed-layer temperatures of $27^{\circ}-28^{\circ} \mathrm{C}$ between $0 \mathrm{~m}$ and

\footnotetext{
Figure 7. (a-g) Shell $\mathrm{Mg} / \mathrm{Ca}$ ratio to $\delta^{18} \mathrm{O}$-derived calcification temperature of various planktic foraminiferal species from this study (black dots and lines) compared to other species-specific temperature calibrations (gray lines). Note that the exponential fits in Figures $7 \mathrm{a}-7 \mathrm{~d}$ (Figures $7 \mathrm{e}-7 \mathrm{~g}$ ) are extrapolated to lower (higher) temperatures than in the original publications, and that all $\mathrm{Mg} / \mathrm{Ca}$ values from this study are at the warm end of the published calibrations. 1a: calibration with calculated exponential value; 1b: calibration with assumed exponential value; 8a: species-specific calibration; 8b: deepdwelling (multispecies) calibration.
} 

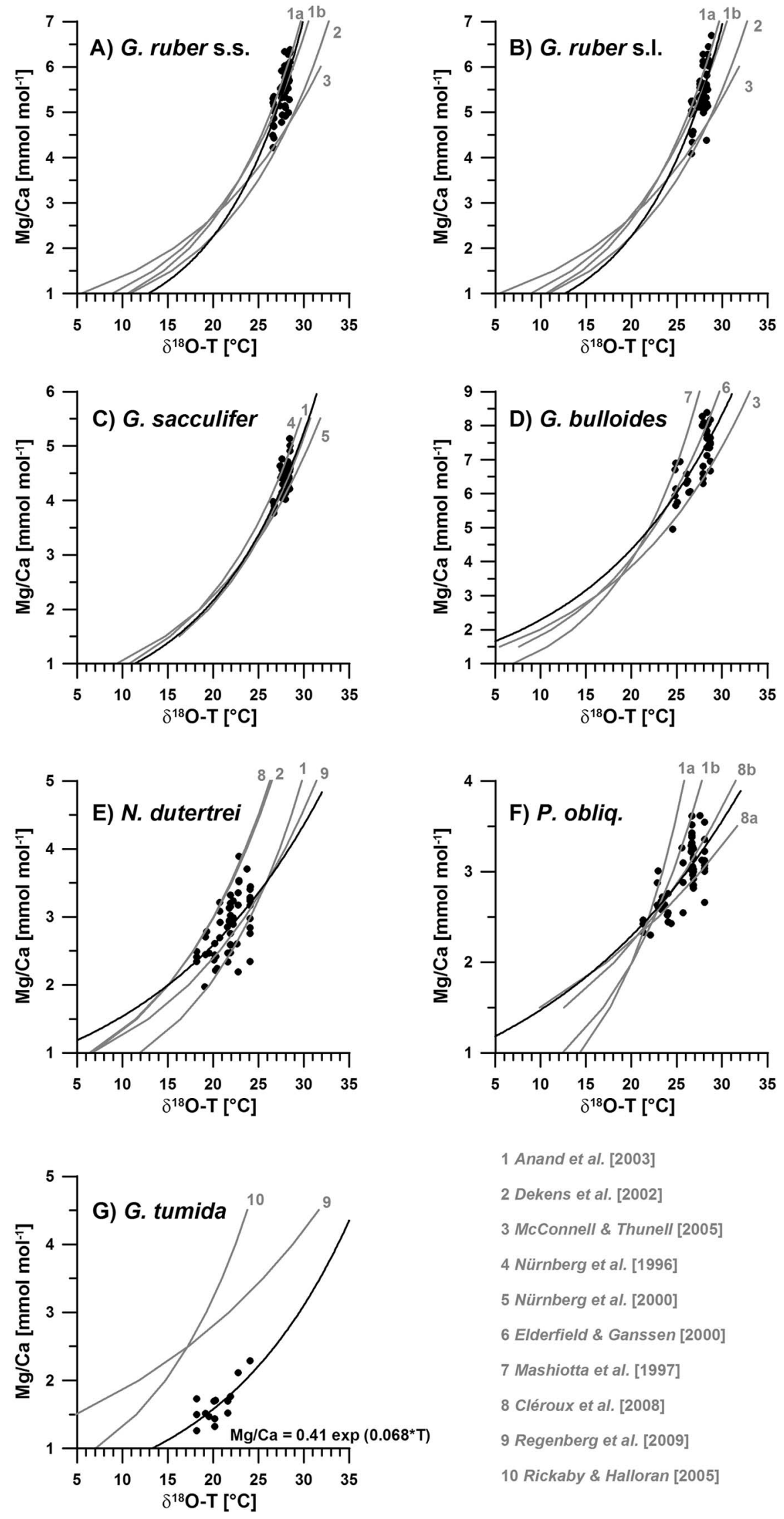

1 Anand et al. [2003]

2 Dekens et al. [2002]

3 McConnell \& Thunell [2005]

4 Nürnberg et al. [1996]

5 Nürnberg et al. [2000]

6 Elderfield \& Ganssen [2000]

7 Mashiotta et al. [1997]

8 Cléroux et al. [2008]

9 Regenberg et al. [2009]

10 Rickaby \& Halloran [2005]

Figure 7 

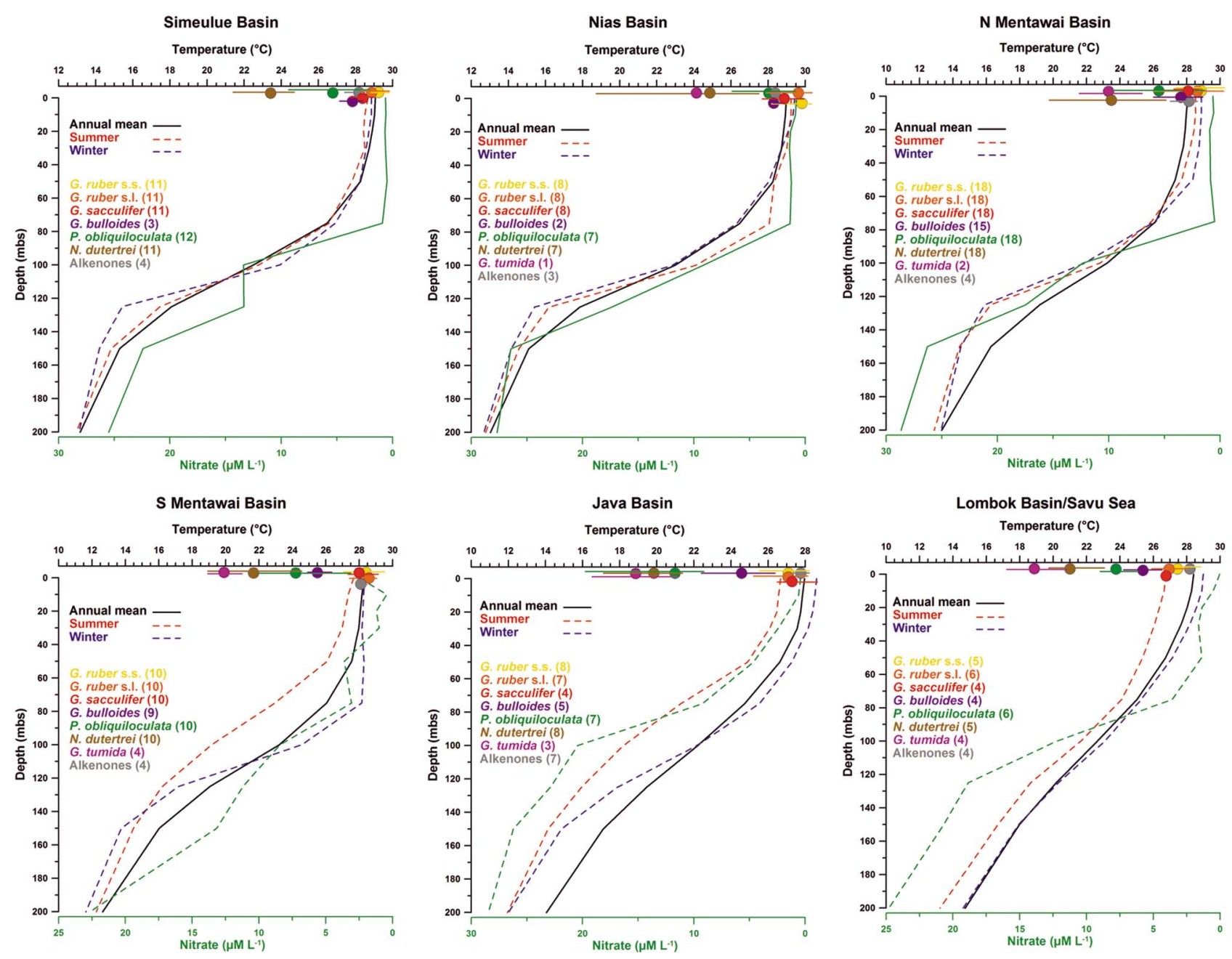

Figure 8. Temperature profiles and nitrate concentration of the upper $200 \mathrm{~m}$ in the different basins of the study area (WOA 05, [Garcia et al., 2006; Locarnini et al., 2006]). Solid black lines: annual mean temperatures; dashed red lines: summer temperatures; dashed blue lines: winter temperatures; solid green lines: annual mean nitrate concentrations in micromole per liter $\left(\mu \mathrm{M} \mathrm{L}^{-1}\right)$; dashed green lines: boreal summer nitrate concentrations; mbs: meter below surface. Color dots indicate average temperatures, calculated from shell $\mathrm{Mg} / \mathrm{Ca}$ ratio of planktic foraminiferal species, and alkenone unsaturation index. Alkenone temperatures are calculated after Conte et al. [2006]. $\mathrm{Mg} / \mathrm{Ca}$-temperatures are calculated using species-specific equations of Anand et al. [2003] for G. ruber s.s., G. ruber s.l., and G. sacculifer, Cléroux et al. [2008] for P. obliquiloculata, Regenberg et al. [2009] for N. dutertrei, Elderfield and Ganssen [2000] for G. bulloides, and own equation for G. tumida. Color lines denote the range of the calculated temperatures in different samples; values in brackets refer to the number of the observed surface sediment samples. The bottom (top) three panels refer to basins that are (not) affected by seasonal upwelling.

$50 \mathrm{~m}$ (Figure 8). Alkenone-based temperatures remain at $\sim 28^{\circ} \mathrm{C}$, suggesting that this proxy can only be used to reconstruct annual mean SST south of $4^{\circ} \mathrm{S}$. It should be noted that alkenone temperatures in the study are at the upper limit of this proxy [e.g., Conte et al., 1998] and might underestimate the growth temperature of the alkenone-producing coccolithophores, particularly during boreal winter when SST is highest. Downcore studies from the study area show a strong seasonal signal in the alkenone-based SST estimates during glacial periods when SSTs lie within the temperature response of alkenone unsaturation [Lückge et al., 2009; Mohtadi et al., 2010]. Hence, it is well possible that alke- nones in surface sediments simply record the limit of their temperature response, which corresponds to modern annual mean SST in the study area but masks their seasonality.

[38] Shell $\mathrm{Mg} / \mathrm{Ca}$ of $\mathrm{G}$. bulloides seems to record summer temperatures ranging between $20 \mathrm{~m}$ and $75 \mathrm{~m}$, with average values reflecting temperatures of $24^{\circ}-26^{\circ} \mathrm{C}$ at the base of the mixed-layer during boreal summer, at $\sim 50 \mathrm{~m}$. Mg/Ca temperatures of $P$. obliquiloculata and $N$. dutertrei reflect upper thermocline temperatures at $\sim 60 \mathrm{~m}\left(21-24^{\circ} \mathrm{C}\right)$ and $\sim 80 \mathrm{~m}$ $\left(20-22^{\circ} \mathrm{C}\right)$ during boreal summer, respectively, thus recording a slightly shallower depth than in the non-upwelling basins. G. tumida appears to record temperatures between 


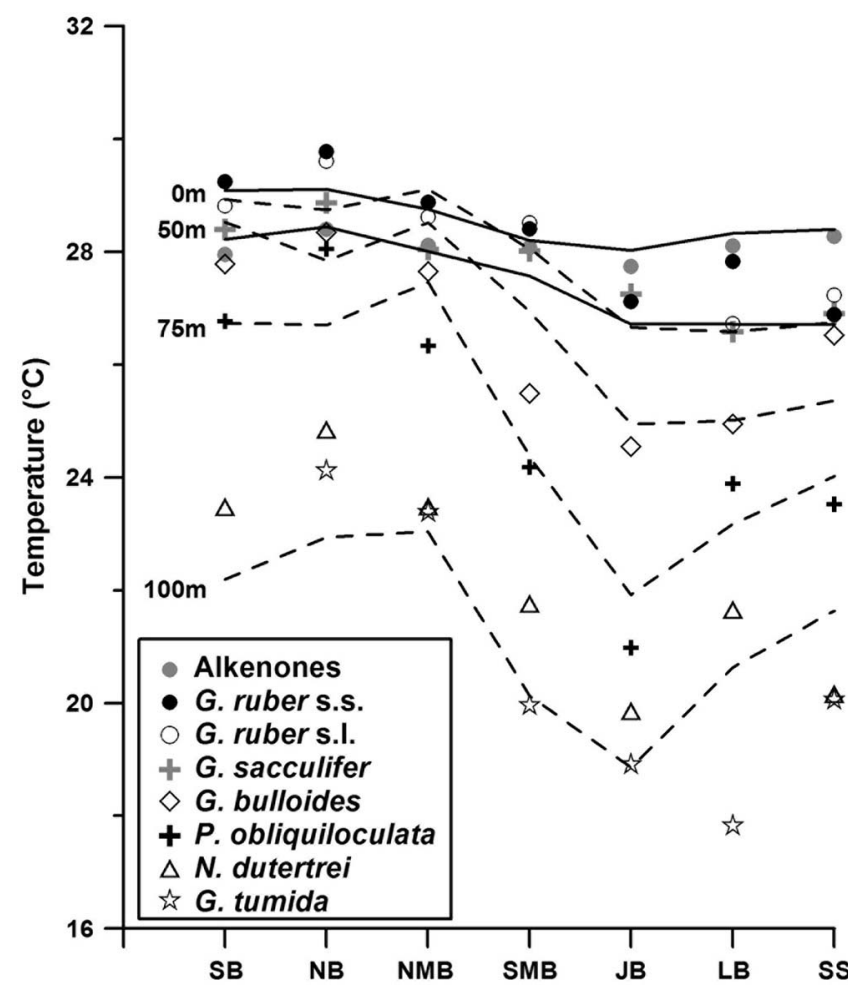

Figure 9. Alkenones- and Shell $\mathrm{Mg} / \mathrm{Ca}$-derived temperatures averaged for each basin. Calibrations are as in Figure 8. Solid lines (dashed lines) indicate annual mean (summer) upper water column temperatures in the different basins at $0 \mathrm{~m}$ and $50 \mathrm{~m}(0-100 \mathrm{~m})$; averaged for each depth at each basin using the WOA 05 database [Locarnini et al., 2006]. SB: Simeulue Basin; NB: Nias Basin; NMB: Northern Mentawai Basin; SMB: Southern Mentawai Basin; JB: Java Basin; LB: Lombok Basin; SS: Savu Sea. The latter four basins are characterized by monsoon-induced seasonal upwelling.

$19^{\circ} \mathrm{C}$ and $20^{\circ} \mathrm{C}$ at $\sim 100 \mathrm{~m}$ depth during boreal summer, at a similar depth as in the northern, non-upwelling basins. In general, these results are in good agreement with the inferred habitat depths from a sediment trap time series in the upwelling area off southern Java [Mohtadi et al., 2009] suggesting habitat depths of $0-30 \mathrm{~m}$ for G. ruber, $60-80 \mathrm{~m}$ for P. obliquiloculata, and $60-90 \mathrm{~m}$ for $N$. dutertrei.

[39] Comparison of the $\mathrm{Mg} / \mathrm{Ca}$ data with the nitrate concentrations in the upper water column further supports previous findings that $G$. bulloides and the thermoclinedwelling species are also bound to the nutricline (Figure 8) [e.g., Fairbanks and Wiebe, 1980]. In particular, N. dutertrei and G. tumida are apparently independent of the thermocline temperature, but dwell at depths characterized by a nitrate concentration of $10-15 \mu \mathrm{M} \mathrm{L}^{-1}$. In general, it appears that temperature changes at the upper thermocline in different basins do not significantly affect the water depth that defines the shell $\mathrm{Mg} / \mathrm{Ca}$ ratio. Rather, the thermocline species appear to track the top of the nutricline that mostly corresponds to the same water depths $(70-100 \mathrm{~m})$, regardless of the absolute temperature values at these depths (Figure 9). For instance, $\mathrm{Mg} / \mathrm{Ca}$-derived temperatures of $P$. obliquiloculata track the summer $75 \mathrm{~m}$ isotherm that represents the upper thermocline (nutricline), although temperatures at this depth vary between $\sim 22^{\circ} \mathrm{C}$ and $\sim 28^{\circ} \mathrm{C}$ in the study area (Figure 9). To this end, our data do not allow a conclusion on whether temperature or nutrient is decisive for the planktic foraminiferal calcification depths. This enterprise requires extensive regional field studies in the future.

[40] In search of a robust proxy for reconstructing past changes in the thermocline depth and/or changes in the upper water column stratification/mixing, our data show that both the pattern and the magnitude of the temperature difference between $G$. ruber s.s. (or G. ruber s.l.) and $P$. obliquiloculata in surface sediments of the study area track the difference between temperatures at $20 \mathrm{~m}$ and at $75 \mathrm{~m}$ from the WOA 05 data (Figure 10a). Likewise, temperature difference between $G$. ruber s.s. and $N$. dutertrei effectively follows the difference between $20 \mathrm{~m}$ and $100 \mathrm{~m}$, suggesting that these differences can be used to track past changes in the water column structure in the eastern equatorial Indian Ocean (Figure 10a). Temperature difference between $G$. bulloides and $P$. obliquiloculata ( $N$. dutertrei) shows the same pattern as observed for the difference between summer temperatures at $50 \mathrm{~m}$ and at $75 \mathrm{~m}(100 \mathrm{~m}$, Figure $10 \mathrm{~b})$. However, the calculated difference between $G$. bulloides and $N$. dutertrei temperatures lies between the WOA 05 difference of $50-75 \mathrm{~m}$ and $50-100 \mathrm{~m}$, which might be due to the $\mathrm{Mg} / \mathrm{Ca}$ temperatures of $N$. dutertrei that reflect temperatures between $75 \mathrm{~m}$ and $100 \mathrm{~m}$ water depth (Figure 9).

[41] Temperature difference between G. sacculifer and thermocline-dwelling species follows the same pattern as observed between G. bulloides (G. ruber s.s.) and thermocline species in the study area (Figure 10c). However, the temperature difference slightly overshoots the expected difference in the JB, and is less than expected in the NB. Finally, the difference between alkenone and G. bulloides temperatures appears to be an appropriate measure of the seasonality of the mixed-layer, as it depicts the difference between annual mean SST and summer temperatures at $50 \mathrm{~m}$ (Figure 10c). However, our results do not resolve the applicability of this proxy for reconstructing seasonality in geological past (see discussion above).

[42] Our study cannot resolve the interannual effect of ENSO and IOD on different proxies at different sites. Since interpretation of past changes in the thermal structure of the water column or seasonality might vary at different sites, a careful understanding of various processes contributing to variance in these proxies is essential. For this purpose, longduration field studies (sediment trap and plankton tow) are required that record the gradient and the entire range of climate variability, and their effect on the here introduced proxies.

\section{Conclusions}

[43] Evaluation of geochemical proxies in modern surface sediments from the eastern equatorial Indian Ocean allows the following conclusions:

[44] Shell $\delta^{18} \mathrm{O}$ and $\mathrm{Mg} / \mathrm{Ca}$ ratio of planktic foraminifera reveal that G. ruber s.s. $(\sim 20 \mathrm{~m})$, G. ruber s.l. $(20-50 \mathrm{~m})$, and $G$. sacculifer $(\sim 50 \mathrm{~m})$ reflect annual mean conditions within the mixed-layer. Calcification depths of these species vary slightly in the different basins of the study area that differ with regard to seasonal changes in temperature and 
productivity, yet still remain within the mixed-layer. $G$. bulloides $(\sim 50 \mathrm{~m})$, P. obliquiloculata $(\sim 75 \mathrm{~m}), N$. dutertrei $(75-100 \mathrm{~m})$, and G. tumida $(\sim 100 \mathrm{~m})$ record boreal summer conditions in nutrient-rich environments at the base of the mixed-layer, and at the upper thermocline, respectively. Our findings from the coastal tropical eastern Indian Ocean are in good agreement with core top results from open ocean
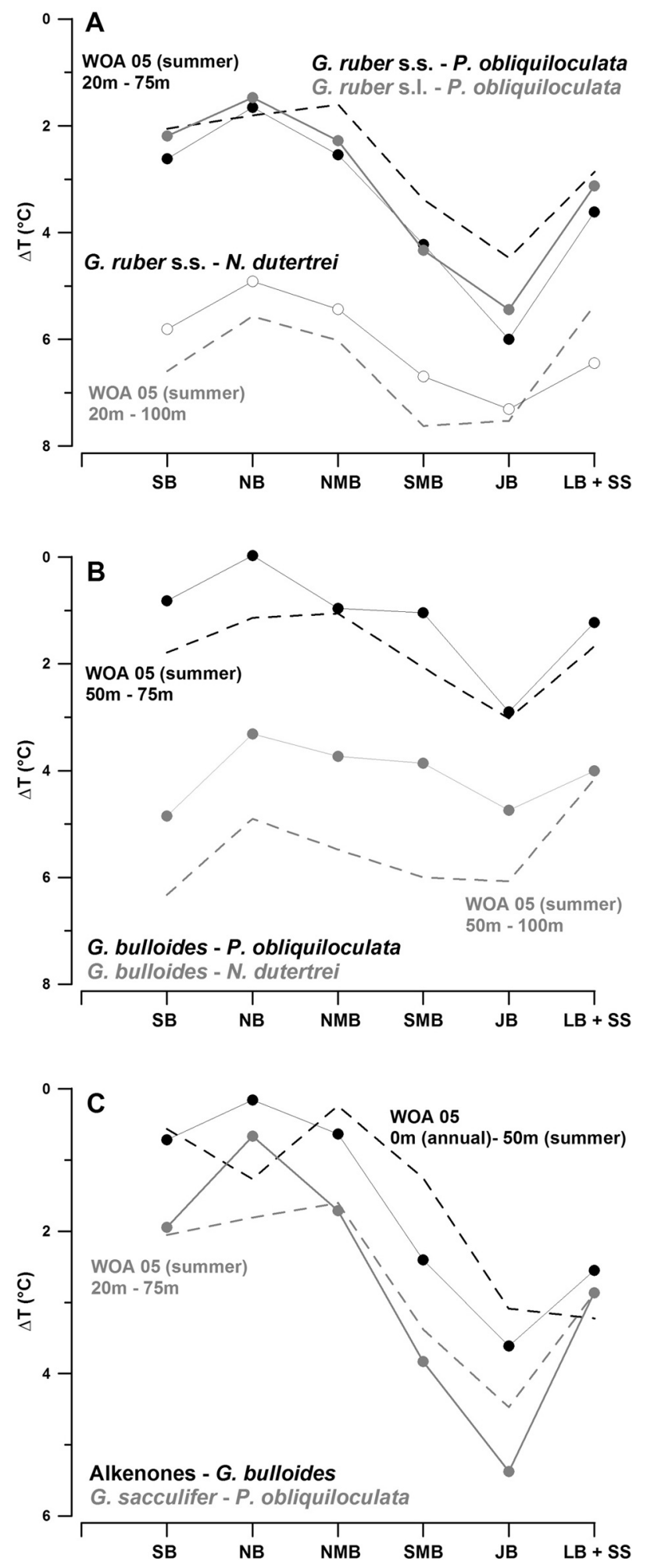

environments [e.g., Elderfield and Ganssen, 2000; Cléroux et al., 2008; Regenberg et al., 2009] and sediment-trap data [e.g., Anand et al., 2003; Mohtadi et al., 2009]. Alkenonebased temperatures record annual mean SST, possibly due to the temperature limitation of this proxy at $\sim 28^{\circ} \mathrm{C}$ that corresponds to annual mean SST in the study area.

[45] Shell $\mathrm{Mg} / \mathrm{Ca}$ ratios of planktic foraminifera significantly correlate to the temperature at their $\delta^{18} \mathrm{O}$-derived calcification depths. $\mathrm{Mg} / \mathrm{Ca}$-temperatures occur at the warm end of the existing species-specific calibrations for planktic foraminifera, except G. tumida that apparently inhabits warmer waters in the study area and therefore, requires a regional $\mathrm{Mg} / \mathrm{Ca}$-temperature calibration $(\mathrm{Mg} / \mathrm{Ca}=0.41$ exp $\left.\left(0.068^{*} \mathrm{~T}\right)\right)$. Conversion of shell $\mathrm{Mg} / \mathrm{Ca}$ to temperature can be best assessed by applying the equations proposed by Anand et al. [2003] for G. ruber s.s., G. ruber s.l., and $G$. sacculifer, by Elderfield and Ganssen [2000] for G. bulloides, by Cléroux et al. [2008] for P. obliquiloculata, and by Regenberg et al. [2009] for $N$. dutertrei.

[46] Temperature difference between the mixed-layer species (G. ruber s.s., G. ruber s.l., and G. bulloides) and the thermocline-species ( $P$. obliquiloculata, $N$. dutertrei) in the study area depicts the temperature difference between the mixed-layer $(20-50 \mathrm{~m})$ and the upper thermocline $(75-$ $100 \mathrm{~m}$ ) during summer, and can be used to reconstruct past changes in the stratification of the upper water column. Temperature difference between alkenones and G. bulloides tracks the present-day difference between annual mean and boreal summer temperatures of the mixed-layer.

[47] Acknowledgments. We are grateful to M. Segl, B. MeyerSchack, C. Gnade, G. Scheeder, E. Alexandrakis, T. Suhr, A. Schwandt, and M. Rashid for laboratory assistance. We are indebted to the Master and the crew of the R/V Sonne for their assistance in collecting the cores used in this study. We thank R. Zahn and three anonymous reviewers for their insightful comments, which greatly improved the overall quality of the manuscript. This project was funded by the German Ministry of Education and Research (BMBF project PABESIA) and the "Deutsche Forschungsgemeinschaft" (DFG project HE 3412/15-1).

Figure 10. (a) $\mathrm{Mg} / \mathrm{Ca}$-based average temperature difference $(\Delta \mathrm{T})$ between $G$. ruber s.s. and P. obliquiloculata (black dots), G. ruber s.l. and P. obliquiloculata (gray dots), and between $G$. ruber s.s. and $N$. dutertrei (black circles) in different basins. Dashed lines represent temperature difference between $20 \mathrm{~m}$ and $75 \mathrm{~m}$ (black), and $20 \mathrm{~m}$ and 100 $\mathrm{m}$ (gray) from the WOA 05 database for boreal summer. (b) $\mathrm{Mg} / \mathrm{Ca}$-based average temperature difference $(\Delta \mathrm{T})$ between $G$. bulloides and $P$. obliquiloculata (black dots), and between $G$. bulloides and $N$. dutertrei (gray dots) in different basins. Dashed lines represent temperature difference between $50 \mathrm{~m}$ and $75 \mathrm{~m}$ (black), and $50 \mathrm{~m}$ and $100 \mathrm{~m}$ (gray) from the WOA 05 database for boreal summer. (c) Difference between average alkenone and $G$. bulloides temperatures (black dots), and between $G$. sacculifer and $P$. obliquiloculata (gray dots) temperatures in different basins. Dashed lines represent temperature difference between annual mean SST $(0 \mathrm{~m})$ and summer temperatures at $50 \mathrm{~m}$ (black), and between $20 \mathrm{~m}$ and $75 \mathrm{~m}$ during boreal summer (gray) from the WOA 05 database. Abbreviations for the different basins are as in Figure 9. 


\section{References}

Anand, P., H. Elderfield, and M. H. Conte (2003), Calibration of $\mathrm{Mg} / \mathrm{Ca}$ thermometry in planktonic foraminifera from a sediment trap time series, Paleoceanography, 18(2), 1050, doi:10.1029/2002PA000846.

Antonov, J. I., R. A. Locarnini, T. P. Boyer, A. V. Mishonov, and H. E. Garcia (2006), World Ocean Atlas 2005, vol. 2, Salinity, NOAA Atlas NESDIS, vol. 62, edited by S. Levitus, 182 pp., NOAA, Silver Spring, $\mathrm{Md}$

Arbuszewski, J., P. deMenocal, A. Kaplan, and E. C. Farmer (2010), On the fidelity of shell-derived $\delta^{18}$ Oseawater estimates, Earth Planet. Sci. Lett., 300(3-4), 185-196, doi:10.1016/j.epsl.2010.10.035.

Barker, S., M. Greaves, and H. Elderfield (2003), A study of cleaning procedures used for foraminiferal $\mathrm{Mg} / \mathrm{Ca}$ paleothermometry, Geochem. Geophys. Geosyst., 4(9), 8407, doi:10.1029/2003GC000559.

Bemis, B. E., H. J. Spero, J. Bijma, and D. W. Lea (1998), Reevaluation of the oxygen isotopic composition of planktonic foraminifera: Experimental results and revised paleotemperature equations, Paleoceanography, 13(2), 150-160, doi:10.1029/98PA00070.

Bouvier-Soumagnac, Y., and J. C. Duplessy (1985), Carbon and oxygen isotopic composition of planktonic foraminifera from laboratory culture, plankton tows and Recent sediment: Implications for the reconstruction of paleoclimatic conditions and of the global carbon cycle, J. Foraminiferal Res., 15, 302-320, doi:10.2113/gsjfr.15.4.302.

Cléroux, C., E. Cortijo, P. Anand, L. Labeyrie, F. Bassinot, N. Caillon, and J.-C. Duplessy (2008), $\mathrm{Mg} / \mathrm{Ca}$ and $\mathrm{Sr} / \mathrm{Ca}$ ratios in planktonic foraminifera: Proxies for upper water column temperature reconstruction, Paleoceanography, 23, PA3214, doi:10.1029/2007PA001505.

Conte, M. H., A. Thompson, D. Lesley, and R. P. Harris (1998), Genetic and physiological influences on the alkenone/alkenoate versus growth temperature relationship in Emiliania huxleyi and Gephyrocapsa oceanica, Geochim. Cosmochim. Acta, 62, 51-68, doi:10.1016/S0016-7037 (97)00327-X.

Conte, M. H., M.-A. Sicre, C. Rühlemann, J. C. Weber, S. Schulte, D. Schulz-Bull, and T. Blanz (2006), Global temperature calibration of the alkenone unsaturation index (UK'37) in surface waters and comparison with surface sediments, Geochem. Geophys. Geosyst., 7, Q02005, doi:10.1029/2005GC001054

d'Orbigny, A. D. (1826), Tableau méthodique de la classe des Céphalopodes, Ann. Sci. Nat., I(7), 1-277.

Darling, K. F., M. Kucera, C. M. Wade, P. von Langen, and D. Pak (2003), Seasonal distribution of genetic types of planktonic foraminifer morphospecies in the Santa Barbara Channel and its paleoceanographic implications, Paleoceanography, 18(2), 1032, doi:10.1029/2001PA000723.

Dekens, P. S., D. W. Lea, D. K. Pak, and H. J. Spero (2002), Core top calibration of $\mathrm{Mg} / \mathrm{Ca}$ in tropical foraminifera: Refining paleotemperature estimation, Geochem. Geophys. Geosyst., 3(4), 1022, doi:10.1029/ $2001 \mathrm{GC} 000200$

Du, Y., T. Qu, and G. Meyers (2008), Interannual Variability of Sea Surface Temperature off Java and Sumatra in a Global GCM, J. Clim., 21(11), 2451-2465, doi:10.1175/2007JCLI1753.1.

Elderfield, H., and G. Ganssen (2000), Past temperature and $\delta^{18} \mathrm{O}$ of surface ocean waters inferred from foraminiferal $\mathrm{Mg} / \mathrm{Ca}$ ratios, Nature, 405, 442-445, doi:10.1038/35013033.

Fairbanks, R. G., and P. H. Wiebe (1980), Foraminifera and chlorophyll maximum: Vertical distribution, seasonal succession, and paleoceanographic significance, Science, 209, 1524-1526, doi:10.1126/science. 209.4464.1524

Fairbanks, R. G., P. H. Wiebe, and A. W. H. Be (1980), Vertical Distribution and Isotopic Composition of Living Planktonic Foraminifera in the Western North Atlantic, Science, 207, 61-63, doi:10.1126/science. 207.4426.61.

Fairbanks, R. G., M. Sverdlove, R. Free, P. H. Wiebe, and A. W. H. Bé (1982), Vertical distribution and isotopic fractionation of living planktonic foraminifera from the Panama Basin, Nature, 298, 841-844, doi:10.1038/298841a0.

Farmer, E. C., A. Kaplan, P. B. d. Menocal, and J. Lynch-Stieglitz (2007) Corroborating ecological depth preferences of planktonic foraminifera in the tropical Atlantic with the stable oxygen isotope ratios of core top specimens, Paleoceanography, 22, PA3205, doi:10.1029/2006PA001361.

Field, D. B. (2004), Variability in vertical distributions of planktonic foraminifera in the California Current: Relationships to vertical ocean structure, Paleoceanography, 19, PA2014, doi:10.1029/2003PA000970.

Galloway, J. J., and S. G. Wissler (1927), Pleistocene foraminifers from the Lomita Quarry, Palos Verdes Hills, California, J. Paleontol., 1, 35-87.

Ganssen, G. (1983), Dokumentation von küstennahem Auftrieb anhand stabiler Isotope in rezenten Foraminiferen vor Nordwest-Afrika, Meteor. Forschungsergeb., Reihe C, 37, 1-46.

Garcia, H. E., R. A. Locarnini, T. P. Boyer, and J. I. Antonov (2006), World Ocean Atlas 2005, vol. 4, Nutrients (Phosphate, Nitrate, and
Silicate), NOAA Atlas NESDIS, vol. 64, edited by S. Levitus, 396 pp., NOAA, Silver Spring, Md

Gordon, A. L. (2005), Oceanography of the Indonesian seas and their throughflow, Oceanography, 18(4), 14-28.

Greaves, M., et al. (2008), Interlaboratory comparison study of calibration standards for foraminiferal $\mathrm{Mg} / \mathrm{Ca}$ thermometry, Geochem. Geophys. Geosyst., 9, Q08010, doi:10.1029/2008GC001974.

Halkides, D. J., W. Han, and P. J. Webster (2006), Effects of the seasonal cycle on the development and termination of the Indian Ocean Zonal Dipole Mode, J. Geophys. Res., 111, C12017, doi:10.1029/2005JC003247.

Hebbeln, D., et al. (2005), Report and preliminary results of RV SONNE cruise SO-184, PABESIA, Durban (South Africa)-Cilacap (Indonesia)Darwin (Australia), July 8th-September 13th, 2005, Rep. 246, 142 pp., Univ. Bremen, Bremen, Germany.

Hemleben, C., M. Spindler, and O. R. Anderson (1989), Modern Planktonic Foraminifera, 363 pp., Springer, New York.

Horii, T., H. Hase, I. Ueki, and Y. Masumoto (2008), Oceanic precondition and evolution of the 2006 Indian Ocean dipole, Geophys. Res. Lett., 35 L03607, doi:10.1029/2007GL032464.

Hughen, K. A., et al. (2004), Marine04 marine radiocarbon age calibration, 0-26 cal kyr BP, Radiocarbon, 46, 1059-1086.

Kida, S., and K. J. Richards (2009), Seasonal sea surface temperature variability in the Indonesian Seas, J. Geophys. Res., 114, C06016, doi:10.1029/2008JC005150.

Kuroyanagi, A., and H. Kawahata (2004), Vertical distribution of living planktonic foraminifera in the seas around Japan, Mar. Micropaleontol. 53(1-2), 173-196, doi:10.1016/j.marmicro.2004.06.001.

Locarnini, R. A., A. V. Mishonov, J. I. Antonov, T. P. Boyer, and H. E. Garcia (2006), World Ocean Atlas 2005, vol. 1, Temperature, NOAA Atlas NESDIS, vol. 61, edited by S. Levitus, 182 pp., NOAA, Silver Spring, Md.

Lückge, A., M. Mohtadi, C. Rühlemann, G. Scheeder, A. Vink, L. Reinhardt and M. Wiedicke-Hombach (2009), Monsoon versus ocean circulation controls on paleoenvironmental conditions off southern Sumatra during the past 300,000 years, Paleoceanography, 24, PA1208, doi:10.1029/ 2008PA001627.

McConnell, M. C., and R. C. Thunell (2005), Calibration of the planktonic foraminiferal $\mathrm{Mg} / \mathrm{Ca}$ paleothermometer: Sediment trap results from the Guaymas Basin, Gulf of California, Paleoceanography, 20, PA2016, doi:10.1029/2004PA001077.

Mohtadi, M., L. Max, D. Hebbeln, A. Baumgart, N. Krück, and T. Jennerjahn (2007), Modern environmental conditions recorded in surface sediment samples off W and SW Indonesia: Planktonic foraminifera and biogenic compounds analyses, Mar. Micropaleontol., 65, 96-112, doi:10.1016/j. marmicro.2007.06.004

Mohtadi, M., S. Steinke, J. Groeneveld, H. G. Fink, T. Rixen, D. Hebbeln, B. Donner, and B. Herunadi (2009), Low-latitude control on seasonal and interannual changes in planktonic foraminiferal flux and shell geochemistry off south Java: A sediment trap study, Paleoceanography, 24, PA1201, doi:10.1029/2008PA001636.

Mohtadi, M., A. Lückge, S. Steinke, J. Groeneveld, D. Hebbeln, and N. Westphal (2010), Late Pleistocene surface and thermocline conditions of the eastern tropical Indian Ocean, Quat. Sci. Rev., 29, 887-896, doi:10.1016/j.quascirev.2009.12.006.

Morimoto, M., O. Abe, H. Kayanne, N. Kurita, E. Matsumoto, and N. Yoshida (2002), Salinity records for the 1997-98 El Niño from Western Pacific corals, Geophys. Res. Lett., 29(11), 1540, doi:10.1029/ 2001GL013521.

Mulitza, S., D. Boltovskoy, B. Donner, H. Meggers, A. Paul, and G. Wefer (2003), Temperature: $\delta^{18} \mathrm{O}$ relationships of planktonic foraminifera collected from surface waters, Palaeogeogr. Palaeoclimatol. Palaeoecol. 202(1-2), 143-152, doi:10.1016/S0031-0182(03)00633-3.

Niebler, H.-S., H.-W. Hubberten, and G. Gersonde (1999), Oxygen isotope values of planktic foraminifera: A tool for the reconstruction of surface water stratification, in Use of Proxies in Paleoceanography: Examples from the South Atlantic, edited by G. Fischer and G. Wefer, pp. 165-189, Springer, Berlin.

Ortiz, J. D., A. C. Mix, and R. W. Collier (1995), Environmental control of living symbiotic and asymbiotic foraminifera of the California Current, Paleoceanography, 10, 987-1009, doi:10.1029/95PA02088.

Peeters, F. J. C. (2000), The distribution and stable isotope composition of living planktic foraminifera in relation to seasonal changes in the Arabian Sea, Ph.D. thesis, 183 pp, Free Univ. of Amsterdam, Amsterdam.

Peeters, F. J. C., G.-J. A. Brummer, and G. Ganssen (2002), The effect of upwelling on the distribution and stable isotope composition of Globigerina bulloides and Globigerinoides ruber (planktic foraminifera) in modern surface waters of the NW Arabian Sea, Global Planet. Change, 34(3-4), 269-291, doi:10.1016/S0921-8181(02)00120-0. 
Qu, T., and G. Meyers (2005), Seasonal characteristics of circulation in the southeastern tropical Indian Ocean, J. Phys. Oceanogr., 35(2), 255-267, doi:10.1175/JPO-2682.1.

Rao, S. A., S. K. Behera, Y. Masumoto, and T. Yamagata (2002), Interannual subsurface variability in the tropical Indian Ocean with a special emphasis on the Indian Ocean Dipole, Deep Sea Res., Part II, 49(7-8), 1549-1572, doi:10.1016/S0967-0645(01)00158-8.

Regenberg, M., S. Steph, D. Nürnberg, R. Tiedemann, and D. GarbeSchönberg (2009), Calibrating $\mathrm{Mg} / \mathrm{Ca}$ ratios of multiple planktonic foraminiferal species with $\delta^{18} \mathrm{O}$-calcification temperatures: Paleothermometry for the upper water column, Earth Planet. Sci. Lett., 278(3-4), 324-336, doi:10.1016/j.eps1.2008.12.019.

Rickaby, R. E. M., and P. Halloran (2005), Cool La Niña During the Warmth of the Pliocene?, Science, 307(5717), 1948-1952, doi:10.1126/science. 1104666 .

Rosenthal, Y., G. P. Lohmann, K. C. Lohmann, and R. M. Sherrell (2000), Incorporation and preservation of $\mathrm{Mg}$ in $\mathrm{G}$. sacculifer: Implications for reconstructing sea surface temperatures and the oxygen isotopic composition of seawater, Paleoceanography, 15, 135-145, doi:10.1029/ 1999PA000415.

Sautter, L. R., and R. C. Thunell (1991), Planktonic foraminiferal response to upwelling and seasonal hydrographic conditions: Sediment trap results from San Pedro Basin, Southern California Bight, J. Foraminiferal Res., 21(4), 347-363, doi:10.2113/gsjfr.21.4.347.

Schmidt, G. A., and S. Mulitza (2002), Global calibration of ecological models for planktic foraminifera from coretop carbonate oxygen-18, Mar. Micropaleontol., 44(3-4), 125-140, doi:10.1016/S0377-8398(01) 00041-X.

Shackleton, N. (1974), Attainment of isotopic equilibrium between ocean water and the benthonic foraminifera genus Uvigerina: Isotopic changes in the ocean during the last glacial, in Les Méthodes Quantitatives d'étude des Variations du Climat au Cours du Pléistocène, edited by L. Labeyrie, pp. 203-209, CNRS, Paris.

Spero, H. J., and D. W. Lea (1996), Experimental determination of stable isotope variability in Globigerina bulloides: Implications for paleoceanographic reconstructions, Mar. Micropaleontol., 28, 231-246, doi:10.1016/ 0377-8398(96)00003-5.

Spero, H. J., K. M. Mielke, E. M. Kalve, D. W. Lea, and D. K. Pak (2003), Multispecies approach to reconstructing eastern equatorial Pacific thermocline hydrography during the past $360 \mathrm{kyr}$, Paleoceanography, 18(1), 1022, doi:10.1029/2002PA000814.

Steph, S., M. Regenberg, R. Tiedemann, S. Mulitza, and D. Nürnberg (2009), Stable isotopes of planktonic foraminifera from tropical Atlantic/
Caribbean core-tops: Implications for reconstructing upper ocean stratification, Mar. Micropaleontol., 71(1-2), 1-19, doi:10.1016/j.marmicro. 2008.12.004.

Susanto, R. D., and J. Marra (2005), Effect of the 1997/1998 El Niño on Chlorophyll $a$ variability along the southern coasts of Java and Sumatra, Oceanography, 18(4), 124-128.

Susanto, R. D., A. L. Gordon, and Q. Zheng (2001), Upwelling along the coasts of Java and Sumatra and its relation to ENSO, Geophys. Res. Lett., 28, 1599-1602, doi:10.1029/2000GL011844.

Tapper, N. J. (2002), Climate, climatic variability and atmospheric circulation patterns in the maritime continent region, in Bridging Wallace's Line: The Environmental and Cultural History and Dynamics of the Southeast Asian-Australian Region, edited by P. Kershaw et al., pp. 5-28, Catena, Reiskirchen, Germany.

Van den Broeck, E. (1876), Etude sur les Foraminiferes de la Barbade (Antilles), Ann. Soc. Belge Microsc., 1, 55-152.

Wang, L. (2000), Isotopic signals in two morphotypes of Globigerinoides ruber (white) from the South China Sea: Implications for monsoon climate change during the last glacial cycle, Palaeogeogr. Palaeoclimatol. Palaeoecol., 161(3-4), 381-394, doi:10.1016/S0031-0182(00)00094-8.

Wiedicke-Hombach, M., et al. (2007), SUMATRA-The hydrocarbon system of the Sumatra forearc, report, 211 pp., Fed. Inst. for Geosci. and Nat. Res., Hannover, Germany.

Zhong, A., H. H. Hendon, and O. Alves (2005), Indian Ocean variability and its association with ENSO in a global coupled model, J. Clim., 18(17), 3634-3649, doi:10.1175/JCLI3493.1.

R. DePol-Holz, Department of Oceanography, University of Concepción, Cabina 7, Barrio Universitario s/n Casilla 160-C, Concepción 3, Chile.

J. Groeneveld, Alfred Wegener Institute for Polar and Marine Research, Columbusstrasse, D-27568 Bremerhaven, Germany.

D. Hebbeln, M. Mohtadi, and S. Steinke, MARUM-Center for Marine Environmental Sciences, University of Bremen, Leobener Str., D-28359 Bremen, Germany. (mohtadi@uni-bremen.de)

N. Hemme, Faculty of Geosciences, University of Bremen, D-28359 Bremen, Germany.

A. Lückge, Federal Institute for Geosciences and Natural Resources, D-30655 Hannover, Germany.

D. W. Oppo, Department of Geology and Geophysics, Woods Hole Oceanographic Institution, 360 Woods Hole Rd., MS 23, Woods Hole, MA 02543, USA. 